\title{
Boosting the productivity and profitability of northern Australian beef enterprises: Exploring innovation options using simulation modelling and systems analysis
}

\author{
Andrew Ash ${ }^{\mathrm{a}, *}$, Leigh Hunt ${ }^{\mathrm{b}, 1}$, Cam McDonald ${ }^{\mathrm{a}}$, Joe Scanlan ${ }^{\mathrm{c}}$, Lindsay Bell ${ }^{\mathrm{d}}$, Robyn Cowley ${ }^{\mathrm{e}}$, Ian Watson ${ }^{\mathrm{f}}$, \\ John McIvor ${ }^{a}$, Neil MacLeod ${ }^{a}$ \\ a CSIRO Agriculture Flagship, EcoSciences Precinct, GPO Box 2583, Brisbane, Queensland 4001, Australia \\ b CSIRO Land and Water Flagship, PMB 44, Winnellie, Northern Territory 0822, Australia \\ c Department of Agriculture and Forestry, PO Box 102, Toowoomba, Queensland 4350, Australia \\ d CSIRO Agriculture Flagship, PO Box 102, Toowoomba, Queensland 4350, Australia \\ e NT Department of Primary Industries and Fisheries, Katherine, Northern Territory, Australia \\ f CSIRO Agriculture Flagship, PMB Aitkenvale, Townsville, Queensland 4814, Australia
}

\section{A R T I C L E I N F O}

\section{Article history:}

Received 22 December 2014

Received in revised form 4 June 2015

Accepted 5 June 2015

Available online $\mathrm{xxxx}$

Keywords:

Extensive beef systems

Technologies

Rangelands

Methane

\begin{abstract}
A B S T R A C T
The financial health of beef cattle enterprises in northern Australia has declined markedly over the last decade due to an escalation in production and marketing costs and a real decline in beef prices. Historically, gains in animal productivity have offset the effect of declining terms of trade on farm incomes. This raises the question of whether future productivity improvements can remain a key path for lifting enterprise profitability sufficient to ensure that the industry remains economically viable over the longer term. The key objective of this study was to assess the production and financial implications for north Australian beef enterprises of a range of technology interventions (development scenarios), including genetic gain in cattle, nutrient supplementation, and alteration of the feed base through introduced pastures and forage crops, across a variety of natural environments. To achieve this objective a beef systems model was developed that is capable of simulating livestock production at the enterprise level, including reproduction, growth and mortality, based on energy and protein supply from natural $C_{4}$ pastures that are subject to high inter-annual climate variability. Comparisons between simulation outputs and enterprise performance data in three case study regions suggested that the simulation model (the Northern Australia Beef Systems Analyser) can adequately represent the performance beef cattle enterprises in northern Australia. Testing of a range of development scenarios suggested that the application of individual technologies can substantially lift productivity and profitability, especially where the entire feedbase was altered through legume augmentation. The simultaneous implementation of multiple technologies that provide benefits to different aspects of animal productivity resulted in the greatest increases in cattle productivity and enterprise profitability, with projected weaning rates increasing by $25 \%$, liveweight gain by $40 \%$ and net profit by $150 \%$ above current baseline levels, although gains of this magnitude might not necessarily be realised in practice. While there were slight increases in total methane output from these development scenarios, the methane emissions per $\mathrm{kg}$ of beef produced were reduced by $20 \%$ in scenarios with higher productivity gain. Combinations of technologies or innovative practices applied in a systematic and integrated fashion thus offer scope for providing the productivity and profitability gains necessary to maintain viable beef enterprises in northern Australia into the future.
\end{abstract}

Crown Copyright $@ 2015$ Published by Elsevier B.V. All rights reserved.

\section{Introduction}

Beef cattle grazing, predominantly of unimproved native vegetation under extensive low-input production systems, is the dominant economic land use of the northern half of the Australian continent (Hunt et al., 2014). The pasture resource base of this geographically diverse

\footnotetext{
* Corresponding author. Tel.: +617 38335638.

E-mail address: andrew.ash@csiro.au (A. Ash).

1 Present address: 6 Gwendoline Court, Coromandel Valley, SA 5051.
}

land mass is comprised of sub-tropical and tropical woodlands, open grasslands and savannas each of which have differing capacities for livestock production and proximity to major livestock markets (Gleeson et al., 2012). The northern grazing lands collectively support around 14 million heads or $60 \%$ of the national beef herd, with a farm gate production value of approximately $\$ 3.7$ billion per annum (Gleeson et al., 2012).

Northern beef enterprises vary considerably in terms of their physical size and geographic spread. Individual properties range from less than 1000 ha carrying fewer than 1000 heads in more developed regions of south-eastern Queensland, to over $1.5 \mathrm{~m}$ ha with in excess of 40,000 
cattle in some cases in north-western Western Australia, the Northern Territory and western Queensland. The native pastures on which cattle production is based are of low nutritive value for much of the year and available pasture biomass is subject to extreme variability in interannual rainfall (Ash et al., 1997).

The northern beef industry has achieved impressive gains in productivity since the 1970s, particularly through the adoption of technological innovations, including the wide-scale replacement of British breed (B. taurus) herds with Zebu (Bos indicus) cattle, improved animal health, nutritional supplements and infrastructure development (Bortolussi et al., 2005). However, despite these gains, the industry faces major economic challenges. For example, the 'terms of trade' for beef production and marketing remain in decline (average trend $-2 \%$ ), with a rapid escalation in production and marketing costs while beef prices have declined in real terms by 15\% since 2005 (Gleeson et al., 2012; ABARES, 2014). In a review of the production and financial health of the northern beef industry in 2010, McCosker et al. (2010) concluded that the sector was in the worst economic shape since a severe beef market crisis in the mid-1970s. An increasing percentage of farm cash receipts required to service rising debt is a major factor in reducing profitability of beef enterprises (Thompson and Martin, 2014). Similar cost pressures are evident in other livestock systems in Australia (Farina et al., 2013) with the response being to explore options for productivity improvements which have been shown to have a major influence on profitability (Crosson et al., 2006).

Technologies with potential to lift productivity in these extensive grazing lands include further genetic gains in cattle reproduction and growth efficiency (Johnston et al., 2014; Wolcott et al., 2014), nutrient and protein supplements (Poppi and McLennan, 2010), the use of superior pasture or fodder species and especially legumes (Mclvor and Monypenny, 1995), and the use of high quality forage crops in intensive animal feeding systems (Bell et al., 2014). The potential advantages of employing these technologies have been empirically evaluated on a relatively piecemeal basis, and rarely within a systems context that facilitates more comprehensive comparisons or allows combinations of technologies to be rigorously tested to see if interactive effects are additive, synergistic or substitutional. Understanding the potential interactions of new technologies as part of an overall grazing system is essential because in practice livestock enterprises will usually be implementing more than one productivity improvement simultaneously (Ashfield et al., 2013; Clark, 2013). Productivity increases do not necessarily lead to improvements in profitability so whole enterprise financial outcomes need to be assessed.

The tropical rangelands of Australia are vulnerable to overgrazing and degradation and a key area of grazing management research and extension over many years has been the development of sustainable carrying capacities (Hunt et al., 2014). Introducing new technologies that allow more animals to be carried and/or to consume more pasture run the risk of creating unintended environmental consequences (Gardener et al., 1990). It is therefore important to be able to appropriately assess the impacts of new technologies on key aspects of landscape health. A more recent environmental concern is the level of methane emissions from the extensive livestock sector, particularly in regions where pasture quality is low such as northern Australia (Cook et al., 2010). Introducing technologies that reduce emissions intensity and offer scope for reducing total methane emissions is therefore desirable.

The use of simulation models provides a cost-effective opportunity to explore the response of extensive livestock grazing enterprises to changes in herd and resource management practices as a result of technological advances (Tess and Kolstad, 2000; Crosson et al., 2006). These enterprises are characterised by complex herd structures and dynamics that are subject to interactions between a highly variable climate and pasture resource, which drives considerable production risk (Cacho et al., 1999). Although a number of beef cattle simulation models have been produced to mimic different production systems around the world (e.g., Foran et al., 1990; Tess and Kolstad, 2000; Teague and Foy, 2002), none of the available models were particularly suited for simulating either extensive production systems in sub-tropical and tropical regions or the types of technology interventions that may be possible for application in the coming two decades. To adequately test these interventions, a model was required that could integrate the growth and quality of natural pastures under grazing, herd dynamics including reproduction, growth and mortality, genetic improvements in reproduction and growth efficiency, alteration of the pasture feed base, provision of nutrient supplements, and rumen modification. This required an ability to model the energy and protein supply consumed by animals and its conversion into animal growth, body condition score and reproductive state.

Within Australia, simulation approaches of livestock systems have been developed that provide some elements of the requirements needed to meet the objectives of this study. Foran et al. (1990) developed a model (Rangepack) for simulating the broad production and financial outcomes for various development options for northern Australian beef enterprises, although this model did not incorporate pasture growth dynamics, and the animal biological parameters were exogenously derived from empirical data and expert opinion rather than endogenously generated by plant and animal process sub-models. Other simulation models that have been specifically developed for northern Australian beef systems do capture the highly variable climate-pasture dynamics (McKeon et al., 2000) but rely on simple empirical relationships established between pasture growth and liveweight gain (McCown, 1981) to drive animal production and enterprise economics (MacLeod et al., 2011). Puig et al. (2011) developed a systems-modelling approach to examine options and trade-offs for development, diversification and land use change in the pastoral lands of northern Australia but they took a broader industry structural approach rather than a focus on 'within enterprise' herd productivity interventions.

Thus, the key objective of this study was to assess the production and financial implications for north Australian beef enterprises of a range of technology interventions (development scenarios), including genetic gain in cattle, nutrient supplementation, and alteration of the feed base through introduced pastures and forage crops, across a variety of natural environments. To achieve this objective a northern beef systems model capable of simulating livestock production at the enterprise level, including reproduction, growth and mortality based on energy and protein supply from natural $\mathrm{C}_{4}$ pastures that are subject to high inter-annual climate variability, was developed. This model is the Northern Australia Beef Systems Analyser (NABSA).

\section{Materials and methods}

\subsection{Model overview}

A brief overview of the NABSA model is provided here; a more detailed description is provided in Appendix A. The model is a wholefarm-scale dynamic simulation model that mimics the response over time of a beef cattle enterprise with a specified herd structure of age and sex classes. The model was developed on a Microsoft Excel ${ }^{\circledR}$ platform and uses a monthly time step. It integrates livestock, pasture and forage crop production with labour and land resource requirements and availability, accounts for component revenue and cost streams, and provides estimates of the expected environmental consequences of various management options. The responses thus include production, economic and environmental dimensions, which are generated as output for each year of a simulation trial and as averages for the trial. A schematic illustration of the structure of the beef production system in northern Australia on which the model was based is presented in Fig. 1. The NABSA model is broadly based on a model structure that was previously developed to simulate smallholder crop-livestock systems in developing countries (Lisson et al., 2010).

The model allows the user to define the size and type of beef enterprise (e.g. breeding, finishing) and initial age and sex class structure relevant to the biophysical features of the region that is being simulated. 


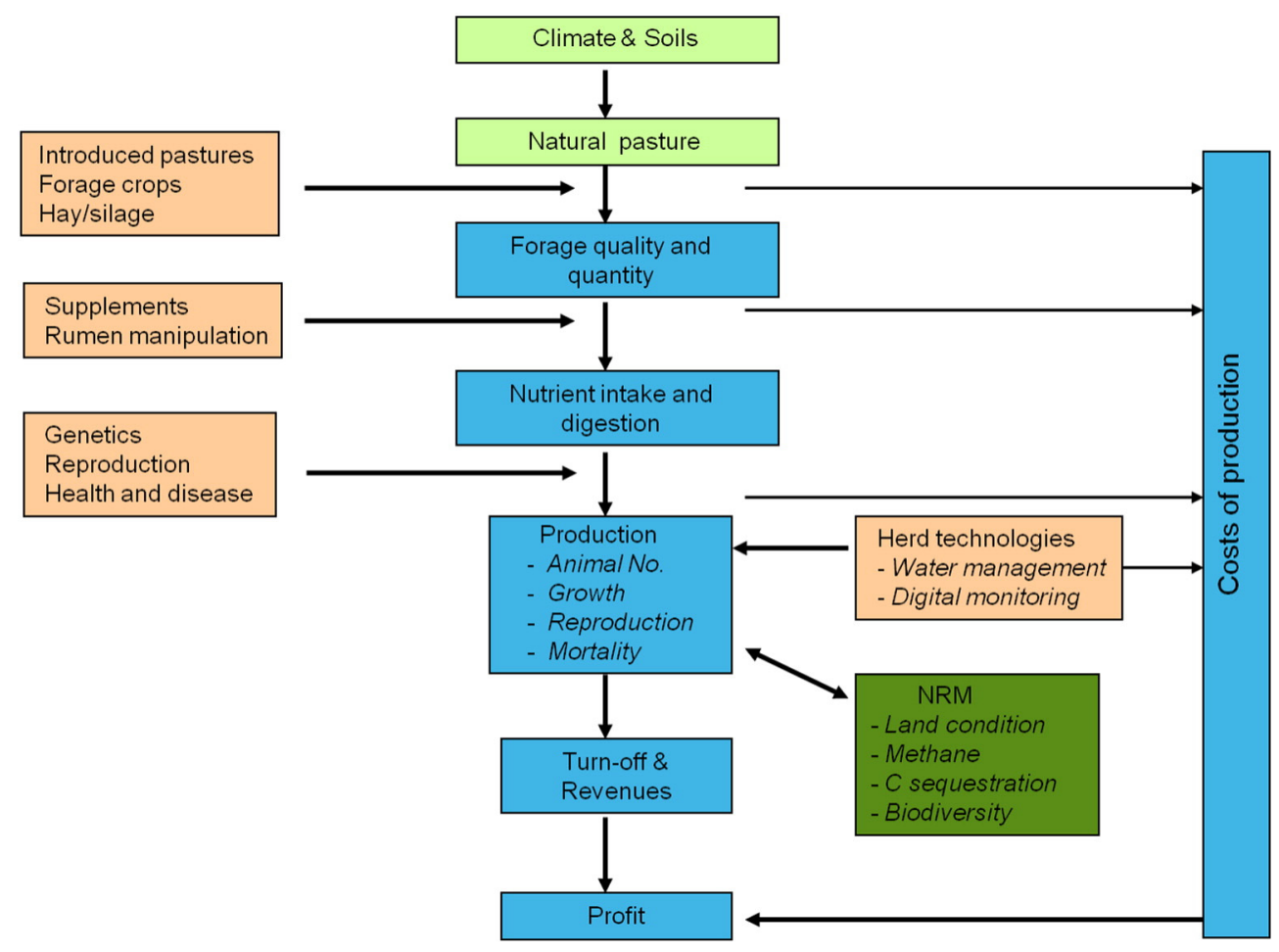

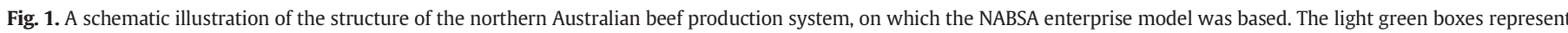

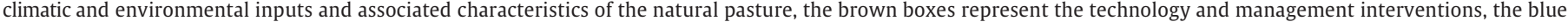

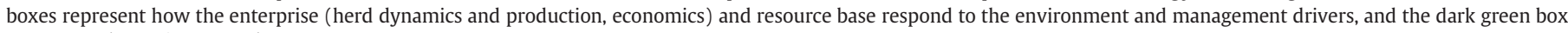
represents the environmental outcomes.

Other input parameters associated with the herd operations include labour supply and demand, direct husbandry and marketing costs (transport, veterinary, fuel, supplementary feeding, etc.), overhead costs, prices per kilogram of liveweight for different animal turn-off classes, rules for sale of animals and feeding and disposal of animals when forage becomes limiting. Forage availability is tracked using 12 monthly forage pools. Forage production is imported at each monthly time-step from external sources, namely the pasture production model GRASP (McKeon et al., 2000) and the crop model APSIM (Keating et al., 2003). These models use an historical climate file and soil description for the relevant study site to capture the inter- and intra-seasonal growth patterns of the available forages that supply the livestock with nutrients. Forage quality declines with age according to specified degradation rates. Mineral or grain supplements or purchased fodder can be used to maintain or improve animal condition when seasonal nutritional deficits occur or during drought.

Simulation of animal growth from birth to turn-off age is based on the available energy and protein supplied by forages and feed supplements using standard relationships for the nutrient requirements of domesticated ruminants (CSIRO, 2007). Conception is determined by the weight of cows relative to a reference weight (the expected weight of an animal in good condition at a given age), which is an effective surrogate for body condition score. The shape of the relationship between body weight-reference weight and conception can be altered and different relationships are used for heifers and more mature cows. Cow mortality rate is also determined by body weight relative to the standard reference weight for that class of animal. Rules are included for sale and purchase of animals. Key settings are the maximum breeder number (which largely determines herd size) and the target weights for sale of steers, surplus heifers and aged cows which generate the flow of animals out of the herd. If animal numbers fall below the target herd size, then additional animals are purchased according to userdefined settings.
The model simulates two key resource condition outcomes - land condition (which influences future forage production) and methane production. Land condition (defined on the basis of the basal area and proportion of desirable perennial grasses) is determined by the pasture utilisation rate (an estimate of total pasture growth that is consumed by animals). High utilisation rates reduce perennial grass basal area and hence land condition and subsequent production (through the selection of relevant data from the forage production database). The user can modify the relationship between pasture utilisation, grass basal area and land condition as these interactions are sensitive to the response of different pasture systems to grazing. The model predicts the dry matter intake of cattle which permits estimation of methane production using a regression relationship developed by Kurihara et al. (1999) and amended by Hunter (2007).

Total gross margins (revenue from sales of turnoff animals minus direct production and marketing costs) and annual net economic profits (total gross margin minus overhead costs) are generated based on livestock sales revenue and enterprise variable and overhead costs, including labour costs and interest paid on outstanding debts. General capital costs (e.g., depreciation and opportunity costs of capital held in livestock, infrastructure and land) are not included but the capital cost for specific development scenarios (e.g., establishing a pasture, specialised animal handling infrastructure) can be included.

As with any model of a complex system, the NABSA model has a number of recognised limitations and simplifying assumptions. Key limitations of the current model include no capacity to handle animal diseases directly (although management costs such as vaccines to minimise their effect can be included, as can alteration in growth or conception curves to reflect disease), no variation among individuals within a given class of animals for key variables such as conception and growth, and no capacity to directly simulate the performance of animals grazing in separate paddocks. Despite these limitations, the key processes operating within typical north Australian beef production systems are 
believed to be well represented, as suggested by favourable validation results (see Section 2.5).

\subsection{Case study regions and enterprises}

Three regions representing different production systems in northern Australia were selected as case studies to explore a range of development scenarios with the NABSA model. These regions are south-east Queensland, northern Queensland and the Victoria River District (VRD) of the Northern Territory (Fig. 2). The simulated development scenarios were applied to the breeding herd of a synthetically constructed beef enterprise in each case-study region. These representative herds were largely produced from consensus data collected from industry workshops held in the regions as part of an earlier study of northern Australian beef production systems (MacLeod et al., 2011), as well as data drawn from several recently published surveys and economic analyses of northern beef enterprises (McCosker et al., 2010; Stockdale et al., 2012). The baseline for these synthetically constructed enterprises included the land area, dominant land type, enterprise type and structure including herd size, market direction, and input costs, etc. in order to accurately simulate the animal turn-off and financial performance that might be currently expected for a typical enterprise in the region. The baseline simulations provided the benchmark to assess the potential production and financial impacts of applying various technology and innovation scenarios. A summary of the regional climate and enterprise characteristics is presented in Table 1 .

\subsection{Development scenarios}

The study was restricted to exploring scenarios to increase the physical productivity of individual animals or the herd in general, although it is recognised that value adding to increase market prices or seeking avenues for reducing costs of production are important aspects of increasing industry profitability. The six innovation scenarios that were explored are presented in Table 2. These scenarios were informed by input from workshops involving disciplinary experts in animal reproduction, genetics, nutrition and pasture management whose focus was identifying options for promoting further productivity gains in extensive beef production systems.
Simulation of each of the six scenarios required specific settings in the NABSA model as follows:

Improved reproduction through genetic gain. The relevant coefficients for the equation relating animal liveweight (body condition) to conception rates (see Appendix A.4) were set to achieve an increase in the average weaning rate of 5 percentage points. This permitted higher rates of conception to occur at the same body condition score. This level of simulated increase in reproductive performance is considered achievable (Johnston et al., 2014).

Improved growth efficiency through genetic gain. The Feeding Standards of Australia (CSIRO, 2007) growth conversion efficiency coefficients were adjusted to achieve a liveweight growth improvement of approximately 10\%. Burrow and Rudder (1991) have demonstrated that efficiencies of this magnitude can be achieved through genetic selection.

Improved rumen function to more effectively metabolise ingested pasture. This scenario assumed an improvement in rumen function through an additive or by modifying rumen function to facilitate better digestion of low quality pasture. This was achieved by reducing the rate at which dry matter digestibility declined each month following pasture senescence (e.g. a monthly decline in digestibility per month of $8 \%$ was used instead of a $10 \%$ decay rate) and the lower limit on digestibility was raised by three percentage points (e.g. from $43 \%$ to $46 \%$ digestibility). This scenario led to increased feed intake in response to higher rumen throughput. Achieving this level of improvement in rumen function appears possible (McSweeney et al., 1999) and is justified in the simulations though practical limitations remain.

Improved pastures. The effect of increased pasture yield from oversowing a native pasture with a legume was simulated by increasing the initial perennial grass basal area by 2 percentage points within the GRASP pasture growth model (e.g. where native grass basal area is $3 \%$ this was increased to $5 \%$ ), which increases forage growth by around $20 \%$. This is consistent with experimental data which shows augmentation of native pasture with legumes can increase pasture biomass by 10-30\% (Mclvor and Gardener, 1995). In NABSA the monthly nitrogen decay rate was reduced from $30 \%$ per month to $10 \%$ per month

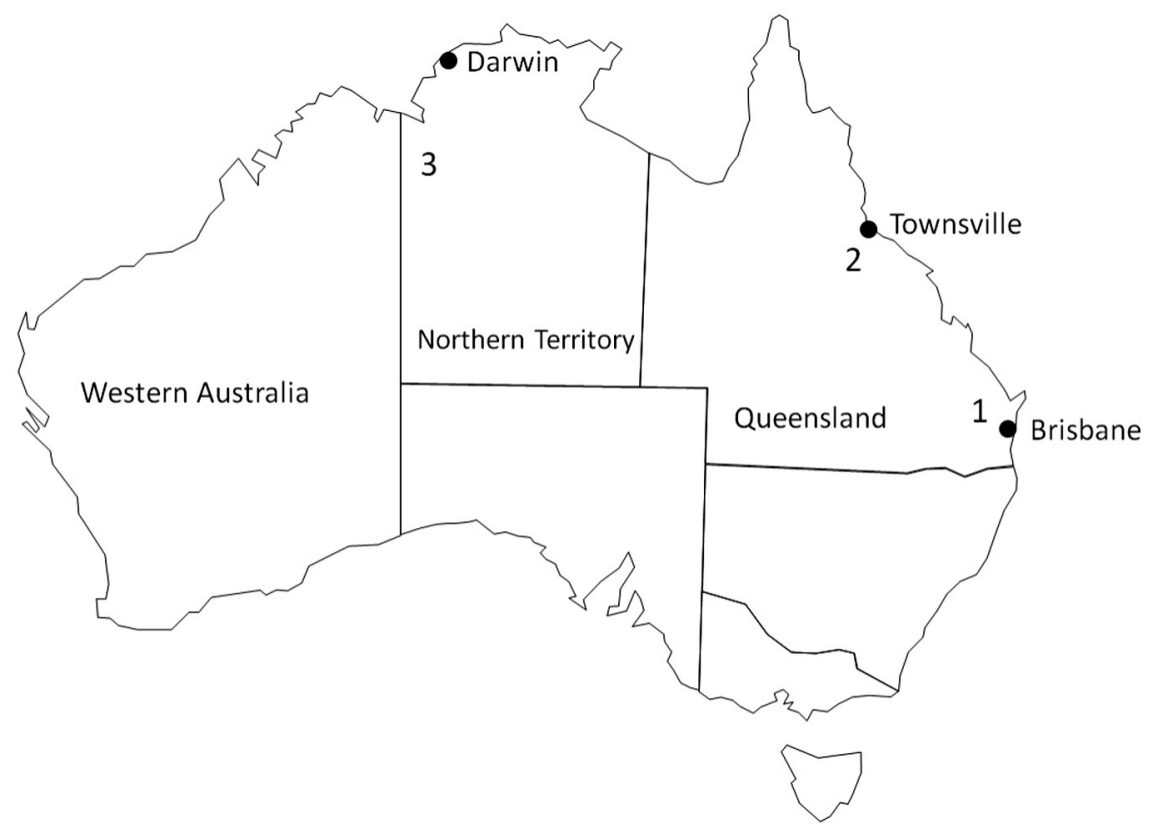

Fig. 2. The general location of the three case study regions. 1, South-east Queensland, 2, Northern Queensland, 3, Victoria River District. 
Table 1

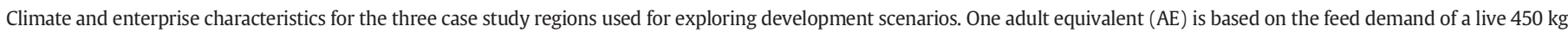
non-pregnant, non-lactating cow.

\begin{tabular}{|c|c|c|c|}
\hline Region & South-east Queensland & Northern Queensland & Victoria River District \\
\hline Climate & Sub-tropical, humid & Semi-arid tropics & Semi-arid tropics \\
\hline Mean rainfall (mm/year) & 760 & 650 & 720 \\
\hline Property size (ha) & 6300 & 30,000 & 550,000 \\
\hline Herd size (Adult Equivalents) & 1600 & 2700 & 19,000 \\
\hline Pasture type & $\begin{array}{l}\text { Mixed native pasture, sown pasture and specialist forages; } \\
\text { with an open woodland structure }\end{array}$ & $\begin{array}{l}\text { Predominately native grasses with a lesser } \\
\text { area augmented with introduced legumes; } \\
\text { with an open savanna canopy tree structure }\end{array}$ & $\begin{array}{l}\text { Predominantly native grasses; } \\
\text { with limited tree and shrub cover }\end{array}$ \\
\hline Production system & Breeding/fattening & Breeding/fattening & Breeding \\
\hline Main target market & Steers ( $550-580 \mathrm{~kg}$ ) for slaughter (export ox) & $\begin{array}{l}\text { Steers }(450-580 \mathrm{~kg} \text { ) for feedlots or slaughter } \\
\text { (export ox) }\end{array}$ & $\begin{array}{l}\text { Young steers and heifers } \\
(350-450 \mathrm{~kg}) \text { for live export }\end{array}$ \\
\hline
\end{tabular}

to simulate the year-round higher protein content of legumeaugmented pastures. The dry matter digestibility decay rate was reduced from $10 \%$ to $9 \%$. The maximum breeder numbers that could be carried were increased in line with the proportionate increase in forage production (typically resulting in herd size being $20 \%$ greater than for the baseline scenario).

Cheap protein supplement. Protein supplementation of low quality tropical pasture can significantly improve animal productivity (McLennan et al., 1995). However, the cost of protein supplements restricts their use. It was assumed that an unspecified new protein source similar in quality to cottonseed meal became available to be fed to cattle in the paddock as a supplement during the dry season for approximately AU $\$ 200 /$ tonne. This price is about one-half of the price that protein supplements of similar quality can presently be fed to animals in the paddock. While such novel protein supplements at that price do not currently exist, the objective was to evaluate the potential from some technologies that are presently under development e.g. low cost on-farm algal protein production.

Combined technologies. To assess the impact of multiple technology improvements, four of the individual scenarios were combined. The four technologies were chosen on the basis that when combined they would likely benefit different aspects of animal production and provide potentially more additive than substitutional impact. It was decided to not use scenarios that significantly altered the feedbase because of the strong regional differences in feedbase benefits and costs. These four individual technologies were genetic gain in reproductive performance, genetic gain in growth efficiency, a cheap protein source and a rumen modifier to improve digestible energy available to the animal. The model was tested using step-wise addition of each of the individual scenarios to test that there were no unusual interactions.

Table 2

An overview of the development scenarios that were modelled for the three beef producing regions.

\begin{tabular}{cl}
\hline Technology/development & Scenarios \\
\hline $\begin{array}{c}\text { Improved reproduction } \\
\text { through genetic gain } \\
\begin{array}{c}\text { Improved growth efficiency } \\
\text { through genetic gain }\end{array}\end{array}$ & $\begin{array}{l}\text { Improved breeder conception rates resulting in } \\
\text { improved calving and weaning percentages } \\
\text { Improved conversion of energy intake for growth }\end{array}$ \\
$\begin{array}{c}\text { Improved rumen function } \\
\text { Improved pastures }\end{array}$ & $\begin{array}{l}\text { More effective metabolism of ingested pasture } \\
\text { Native pastures oversown with legumes to increase } \\
\text { pasture yield and improve pasture quality }\end{array}$ \\
Cheap protein supplement figh quality low-cost protein supplement fed to all \\
& $\begin{array}{l}\text { classes of cattle during the protein-deficient dry } \\
\text { season } \\
\text { Simultaneous application of the better breeder } \\
\text { genetics, better genetics for growth, rumen } \\
\text { modification and cheap protein supplement scenarios }\end{array}$ \\
\hline
\end{tabular}

Simulation trials were undertaken for a 25-year period of historical climate for each case-study region (i.e. 1985-2010) to provide exposure to a wide range of climatic variability. While the full impact of some development scenarios would, in reality, require many years to take effect (e.g. the introduction of improved genetics), the simulation trials were undertaken without a ramp-up period and an assumption was made that they would have been fully implemented or established from the start of the scenario runs. Where significant costs could be attributed to the scenario these were included in the financial analysis. For example, sowing of legumes was assumed to be a large upfront capital cost and given the baseline scenario assumed no starting cash on hand, this incurred a starting debt. Profits were used to reduce the debt as soon as possible. Supplementation incurred additional costs on a recurring basis through the simulation. Genetic improvement is an ongoing cost for most producers e.g. purchase of bulls and these costs were captured in the model. The costs associated with improved herd recording to achieve genetic gains were assumed to be absorbed within existing labour costs.

A key issue for exploring the various scenarios was to ensure that the new technologies or practices embodied within them could be implemented sustainably and not lead to overgrazing and land degradation. Consequently, the total numbers of breeders carried in the model herds were adjusted in the various simulation trials through a parameter that sets maximum breeder numbers so as to maintain safe pasture utilisation rates to maintain or improve land condition over the length of each trial. There has been considerable effort to determine sustainable utilisation rates for tropical rangelands in northern Australia (e.g., Scanlan et al., 1994; Walsh and Cowley, 2011) and this information was used in setting stock numbers to achieve safe utilisation rates in the simulation runs.

\subsection{Input data}

The age and sex class structure of the simulated beef herd for each case-study region and the main class and age/condition of turn-off animals were based on a herd dynamics approach that was previously developed by MacLeod et al. (2004) to track changes in the cohort size of different age and sex classes over time. Historical records of daily climate were obtained from the SILO database (www. longpaddock.qld.gov.au) based on the most relevant climate station within each case-study region and this data was incorporated into the GRASP and APSIM pasture and crop models. This ensured that the large interannual variability in climate and its influence on pasture and animal productivity and resource condition that characterises the northern Australian semi-arid tropics (Ash et al., 1997) was captured in the simulation studies. Pasture quality data from Near Infrared Spectroscopy (NIRS) analysis of cattle dung from free ranging cattle in different parts of northern Australia (e.g., Coates and Dixon, 2008) were used to specify pasture quality in the model. 
Table 3

Comparison of key production and economic indicators between the NABSA model output for baseline scenarios, regional herd data developed by the Co-operative Research Centre for Beef Genetic Technologies (CRCBGT) for the three case study regions (Holmes, 2011), and a large empirical study of reproductive performance in northern Australia (McGowan et al., 2014). Northern Queensland is represented by an average of the Northern Downs and Northern Forest regions in the study of McGowan et al. (2014).

\begin{tabular}{|c|c|c|c|c|}
\hline Region & & $\begin{array}{l}\text { Weaning rate } \\
(\%)\end{array}$ & $\begin{array}{l}\text { Weaning weight } \\
\text { (kg liveweight) }\end{array}$ & Gross margin $(\$ / A E)$ \\
\hline South-east & Holmes & 71 & 190 & $132^{\mathrm{a}}$ \\
\hline \multirow[t]{2}{*}{ Queensland } & McGowan & 76 & 233 & \\
\hline & Model & 69 & 212 & 162 \\
\hline Northern & Holmes & 61 & 180 & 152 \\
\hline \multirow[t]{2}{*}{ Queensland } & McGowan & 62 & 181 & \\
\hline & Model & 58 & 186 & 135 \\
\hline Victoria River & Holmes & 56 & 160 & 114 \\
\hline \multirow[t]{2}{*}{ District } & McGowan & 53 & 163 & \\
\hline & Model & 51 & 164 & 101 \\
\hline
\end{tabular}

${ }^{\mathrm{a}}$ This is a productive region but small average herd numbers and low economies of scale drive down financial performance.

\subsection{Model validation}

The key biological and economic parameter values that were used in the model were validated by comparing the results from the baseline model simulations with a comprehensive set of regional herd data that was developed by the Co-operative Research Centre for Beef Genetic Technologies (CRCBGT - http://www.beefcrc.com/) to undertake cost-benefit analyses for the introduction of genetic technologies into northern beef herds (Holmes, 2011). In addition, a recently completed major study of reproductive performance of northern Australian beef herds provided a rigorous empirical dataset of biological performance (McGowan et al., 2014). Table 3 shows there is reasonable agreement between the NABSA model output and the results of Holmes (2011) and McGowan et al. (2014) for weaning percentage (weaners produced per breeders mated), weaning weight and gross margin per adult equivalent. This gives confidence that the model was adequately simulating these production systems.

\section{Results}

Summaries of the main biological and financial outcomes from the different production technologies when simulated in the beef enterprises in each of the three regions are presented in Tables 4-6.

\subsection{Production and financial performance}

All development scenarios led to increases in beef produced, gross margin and profit in each of the three regions, but there were marked differences amongst regions and development scenarios in these responses. The average increase in profit across all scenarios was $87 \%$ in the VRD region, $62 \%$ for northern Queensland and $48 \%$ for south-east Queensland. Overall, the combined technologies gave the greatest response in productivity and financial performance, followed by improved pastures $>$ cheap protein supplement $>$ improved rumen function $>$ improved growth efficiency $>$ improved reproduction. The only case where this sequence did not occur was in the VRD where improved rumen function and cheap protein supplementation switched order. Although the trend in response to the development scenarios was largely consistent across the regions, the relative magnitude of the response compared with the baseline differed amongst regions. These differences appear to be related to the underlying productivity of each region. The south-east Queensland region (Table 4) was the most productive and profitable region in terms of individual animal performance and gross margin per $\mathrm{AE}$ but had the least response in relative terms to the different development scenarios. In contrast, the Victoria River District region (Table 6) was the least productive as measured by weaning rate, growth rate and gross margin but it had the greatest response to the various technology interventions. The decline in baseline productivity from south to north and west to the Victoria River District reflects a decline in the quality of pastures along this gradient.

The genetics scenarios (improved reproduction and growth efficiency) produced lower gains in productivity and financial performance than the other development scenarios. This in part reflects a more modest intervention e.g., for the improved reproduction scenario there was a 5 percentage point increase in weaning rate, with no change to growth of animals. Some of the other nutritional based scenarios lifted growth of all animals which led to higher weaning rates and increased growth. Nevertheless, increasing weaning rate by 5 percentage points resulted in a 20\% (range 13-26\%) increase in average annual net profit despite the growth rates of individual animals not being directly affected.

Increasing efficiency of growth through genetic gain resulted in a consistent increase of $16 \mathrm{~kg} / \mathrm{head} /$ year in liveweight gain across the three case-study regions, which also had some minor flow-on benefits for cow condition and calf weaning rates (which increased on average by 3 percentage points). However, improvements in financial performance were not consistent across regions with the increase in liveweight gain and weaning rate generating a relatively greater gross margin per animal compared with the baseline scenario in the VRD (25\%) than in northern or south-east Queensland (8\%). Overall stocking rate, as measured by AEs, did not change much over the baseline because of the more rapid turn-off of growing animals.

Table 4

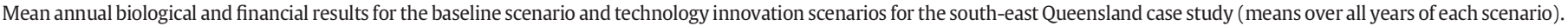

\begin{tabular}{|c|c|c|c|c|c|c|c|}
\hline Scenario & Baseline & $\begin{array}{l}\text { Breeder } \\
\text { genetics }\end{array}$ & $\begin{array}{l}\text { Growth } \\
\text { genetics }\end{array}$ & $\begin{array}{l}\text { Rumen } \\
\text { modifier }\end{array}$ & $\begin{array}{l}\text { Improved } \\
\text { pasture }\end{array}$ & $\begin{array}{l}\text { Cheap } \\
\text { protein }\end{array}$ & $\begin{array}{l}\text { Combined } \\
\text { technologies }\end{array}$ \\
\hline Herd size (AE) & 1697 & 1725 & 1701 & 1734 & 1859 & 1784 & 1787 \\
\hline Weaning rate $(\%)$ & 69 & 74 & 72 & 77 & 72 & 74 & 81 \\
\hline Weaning weight (kg) & 212 & 211 & 215 & 232 & 214 & 221 & 231 \\
\hline Growth rate (kg/head/year) & 140 & 140 & 156 & 158 & 168 & 173 & 196 \\
\hline Beef turned off $(\mathrm{kg})$ & 240,236 & 250,758 & 253,771 & 263,945 & 281,219 & 279,118 & 297,626 \\
\hline Methane ( $\mathrm{kg} \mathrm{CO}_{2} \mathrm{e} / \mathrm{ha} /$ year) & 533 & 545 & 523 & 538 & 595 & 563 & 545 \\
\hline Methane intensity $\left(\mathrm{kg} \mathrm{CO}_{2} \mathrm{e} / \mathrm{kg}\right.$ beef produced) & 15.5 & 15.2 & 14.4 & 14.3 & 14.9 & 14.1 & 12.8 \\
\hline Pasture utilisation (\%) & 31 & 31 & 30 & 31 & 32 & 31 & 30 \\
\hline Gross margin $(\$ / \mathrm{AE})$ & 162 & 169 & 175 & 182 & 207 & 194 & 218 \\
\hline Profit (\$) & 127,335 & 144,126 & 151,825 & 168,623 & 236,266 & 189,225 & 242,824 \\
\hline
\end{tabular}


Table 5

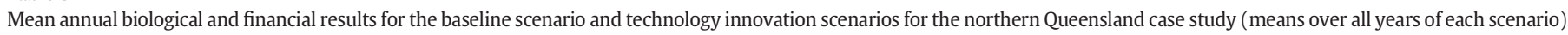

\begin{tabular}{|c|c|c|c|c|c|c|c|}
\hline Scenario & Baseline & $\begin{array}{l}\text { Breeder } \\
\text { genetics }\end{array}$ & $\begin{array}{l}\text { Growth } \\
\text { genetics }\end{array}$ & $\begin{array}{l}\text { Rumen } \\
\text { modifier }\end{array}$ & $\begin{array}{l}\text { Improved } \\
\text { pasture }\end{array}$ & $\begin{array}{l}\text { Cheap } \\
\text { protein }\end{array}$ & $\begin{array}{l}\text { Combined } \\
\text { technologies }\end{array}$ \\
\hline Herd size $(\mathrm{AE})$ & 2901 & 2980 & 3014 & 3122 & 3476 & 3170 & 3184 \\
\hline Weaning rate (\%) & 58 & 63 & 61 & 64 & 69 & 69 & 76 \\
\hline Weaning weight (kg) & 196 & 195 & 197 & 203 & 203 & 207 & 212 \\
\hline Growth rate $(\mathrm{kg} / \mathrm{head} / \mathrm{year})$ & 127 & 127 & 143 & 144 & 154 & 151 & 180 \\
\hline Beef turned off $(\mathrm{kg})$ & 331,091 & 354,421 & 361,482 & 388,432 & 452,459 & 413,481 & 466,981 \\
\hline Methane $\left(\mathrm{kg} \mathrm{CO}_{2} \mathrm{e} / \mathrm{ha} /\right.$ year$)$ & 205 & 213 & 208 & 218 & 250 & 223 & 220 \\
\hline Methane intensity $\left(\mathrm{kg} \mathrm{CO}_{2} \mathrm{e} / \mathrm{kg}\right.$ beef produced) & 18.7 & 18.1 & 17.4 & 16.9 & 16.7 & 16.3 & 14.3 \\
\hline Pasture utilisation (\%) & 27 & 28 & 28 & 29 & 24 & 28 & 28 \\
\hline Gross margin $(\$ / A E)$ & 125 & 133 & 135 & 143 & 153 & 147 & 174 \\
\hline Profit (\$) & 165,607 & 199,790 & 209,797 & 245,362 & 335,255 & 259,659 & 358,693 \\
\hline
\end{tabular}

Simulating a modest improvement in rumen function through reducing slightly the seasonal decline in dry matter digestibility and lifting the minimum digestibility by 3 percentage points (e.g. $42 \%$ to $45 \%$ ) resulted in large gains in productivity and financial performance. The weaning rate increased by 7 percentage points and liveweight gain by an average of $20 \mathrm{~kg} /$ head/year, which led to average increases in gross margin of $\$ 20$ per adult equivalent and an average increase in annual net profit of 57\%. The large response in net profit was in large part due to a greater herd size being carried with more animals being turned off for sale. The increase in herd size was not driven by a deliberate increase in breeder numbers but occurred as a result of higher growth rates and weaning rates driving up herd numbers, but not significantly enough to compromise land condition.

Improved pasture resulted in significant gains in both animal productivity and enterprise profitability in all three case-study regions. These gains were a result of both improved liveweight gain per animal (average $29 \mathrm{~kg} / \mathrm{head} /$ year increase over baseline) and increased weaning rate. There was a wide variation between regions in the increase in weaning rate with south-east Queensland showing a 3 percentage point increase in weaning rate compared with 11 and 12 percentage point increase for north Queensland and the VRD, respectively. An increased herd carrying capacity (average increase of 17\%) facilitated by higher levels of pasture production also contributed significantly to the large increase in gross margin and profit in this scenario.

Providing a cheap high quality protein supplement resulted in significant increases in productivity and profitability in all regions. The gains can be attributed to a combination of factors including being able to support a small increase in herd carrying capacity (average of $8 \%$ over the baseline), improved animal liveweight gains (16-33 kg/head/annum) and significant improvements in the weaning rate (5-12 percentage points). Interestingly, the increase in liveweight gain in response to the protein supplement was greatest is south-east Queensland and least in the VRD region. Given the seasonal decline in protein content is more severe in the VRD, this result appears surprising. However, the very low digestibility of pastures in the VRD region during the time at which protein supplement was being provided may have limited the response to the additional protein. The effect of this was to reduce the increase in profit of the cheap protein scenario in the VRD below that of the rumen modification scenario.

The scenario of the combined technologies (genetic gains in reproduction and growth efficiency, improved rumen function and cheap protein supplementation) led to the greatest gains in productivity and profitability. Weaning rates increased by an average of $28 \%$, liveweight gain by $41 \%$ and net profit increased by $130 \%$. The gains in productivity tended to be relatively higher in the VRD and northern Queensland regions, especially in weaning rate, and this was amplified in the financial outcomes for these two regions.

\subsection{Herd dynamics}

Beef production systems in northern Australia are dominated by breeding operations. The size and structure of breeding herds are particularly dynamic over time with, for example, decisions on managing the breeding herd (e.g. selling off stock in drought, or retaining older breeders for mating in good seasons) having an ongoing impact for many years. As a consequence, a major structural impact of the simulated application of technologies is to alter herd dynamics in a significant way. This is especially so for interventions that can substantially lift productivity and result in animals being turned off at a younger age. This is illustrated in Fig. 3 for the northern Queensland case study, which shows the stochastic nature of the herd size under the baseline scenario compared with the combined technologies. Herd sizes for both scenarios tracked closely for a few years until a severe drought was encountered in the early to mid-1990s. In the case of the highly productive, combined technologies scenario cattle numbers built up again rapidly after the drought. However, in the baseline scenario cattle numbers did not recover significantly before a second series of drought years from 2002-2005 kept

Table 6

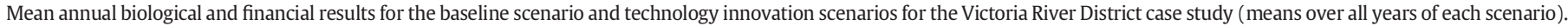

\begin{tabular}{|c|c|c|c|c|c|c|c|}
\hline Scenario & Baseline & $\begin{array}{l}\text { Breeder } \\
\text { genetics }\end{array}$ & $\begin{array}{l}\text { Growth } \\
\text { genetics }\end{array}$ & $\begin{array}{l}\text { Rumen } \\
\text { modifier }\end{array}$ & $\begin{array}{l}\text { Improved } \\
\text { pasture }\end{array}$ & $\begin{array}{l}\text { Cheap } \\
\text { protein }\end{array}$ & $\begin{array}{l}\text { Combined } \\
\text { technologies }\end{array}$ \\
\hline Herd size (AE) & 18,721 & 19,149 & 18,566 & 21,836 & 22,723 & 21,159 & 23,341 \\
\hline Weaning rate (\%) & 51 & 56 & 55 & 59 & 63 & 63 & 69 \\
\hline Weaning weight $(\mathrm{kg})$ & 164 & 163 & 165 & 176 & 177 & 176 & 176 \\
\hline Growth rate $(\mathrm{kg} / \mathrm{head} / \mathrm{year})$ & 125 & 125 & 141 & 150 & 157 & 141 & 175 \\
\hline Beef turned off $(\mathrm{kg})$ & $1,878,068$ & $2,044,545$ & $2,171,352$ & $2,474,519$ & $2,716,907$ & $2,583,052$ & $3,155,812$ \\
\hline Methane $(\mathrm{kg} \mathrm{CO} 2 \mathrm{e} / \mathrm{ha} /$ year $)$ & 75 & 78 & 73 & 85 & 93 & 85 & 90 \\
\hline Methane intensity $\left(\mathrm{kg} \mathrm{CO}_{2} \mathrm{e} / \mathrm{kg}\right.$ beef produced) & 21.9 & 20.8 & 18.4 & 19.2 & 18.8 & 18.1 & 16.0 \\
\hline Pasture utilisation (\%) & 8.8 & 9.2 & 8.6 & 10.2 & 10.4 & 9.6 & 10.8 \\
\hline Gross margin $(\$ / A E)$ & 101 & 112 & 126 & 125 & 135 & 121 & 151 \\
\hline Profit (\$) & 912,766 & $1,151,676$ & $1,345,925$ & $1,748,586$ & $1,911,540$ & $1,556,365$ & $2,518,827$ \\
\hline
\end{tabular}




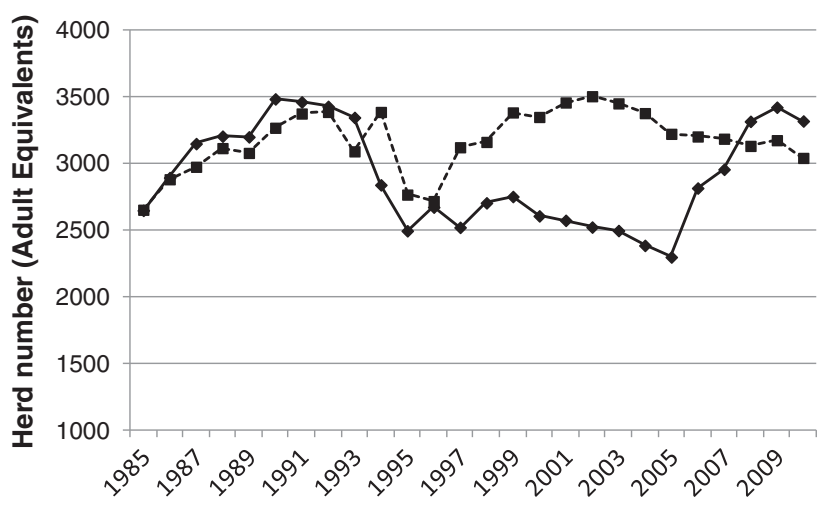

Fig. 3. Comparison of herd size between the baseline scenario (solid line) and the combined technologies scenario (dashed line) in the northern Queensland enterprise.

numbers at lower levels compared with those under the combined technologies scenario. Cattle numbers under the baseline scenario recovered in the second half of the decade when a sequence of better years was experienced. By the end of the simulation run herd numbers were higher in the baseline scenario following the sequence of good seasons because the set breeder number in the combined technologies scenario was lower than in the baseline because of its higher productivity in reproduction and growth. Overall, herd numbers were also less volatile in the combined technologies scenario because it was less vulnerable to the impacts of drought.

This asynchronous pattern between the baseline and the combined technologies scenario is even more evident in terms of simulated net profit, as shown in Fig. 4 for the south-east Queensland regional case study. In the two scenarios, the animals reach their specified sale weights at completely different times, with the spikes in net profit in the combined technologies scenario being the result of two age cohorts of animals reaching the target sale weight within a single year.

\subsection{Environmental performance}

The model can simulate the environmental impacts of different strategies in two areas. The first is through the feedback effects of grazing and pasture utilisation on land condition and soil erosion. In this study of different technology interventions, herd numbers were constrained to

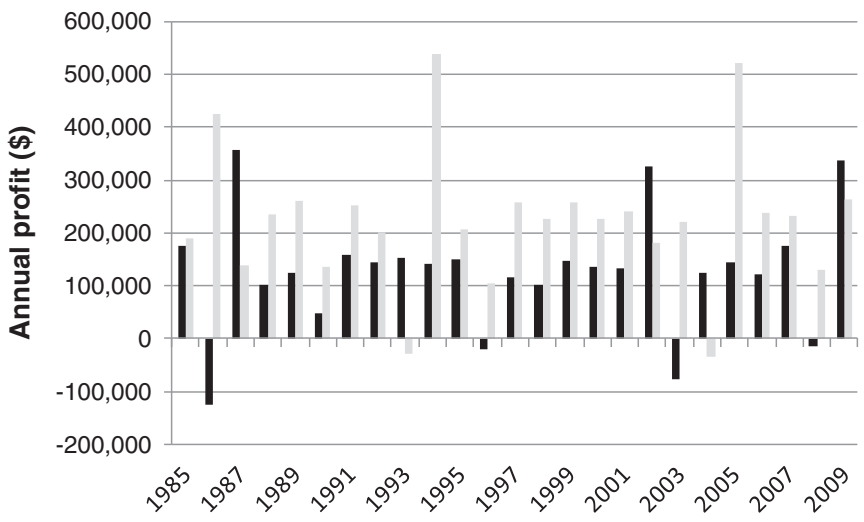

Fig. 4. Comparison of annual profit between the baseline scenario (black bars) and the combined technologies scenario (grey bars) in the south-east Queensland enterprise. levels of pasture utilisation that were considered sustainable to avoid confounding the effects of the technologies with changes in land condition. As a consequence, the effects of the interventions on land condition are not reported in this paper.

Methane production is the second area where the model can simulate the effects of different intervention strategies on environmental performance. A general finding from the simulations that is consistent across all of the technologies and regional locations, is that total production of methane per hectare increased in scenarios with greater levels of animal productivity, kilograms of beef produced per hectare and profit (Fig. 5a). In contrast, the intensity of methane production (i.e. the amount of methane per kilogram of beef produced) decreased under scenarios of higher productivity and profit (Fig. 5b). The projected average reduction in methane intensity was $23 \%$, which is consistent with the increases in overall total kilograms of beef turned off. However, the increase in overall methane production averaged $10 \%$ because the decrease in intensity of methane production nearly offset the higher methane production from higher levels of beef production.

The trade-off between profit and methane production exhibited a similar pattern across all regions (Table 7, data for two regions presented). If some of the gains in profit from introducing technologies are foregone by reducing the herd size in order that methane production per hectare does not increase over the baseline, then net profit is reduced by about 10\% in northern Queensland and around 25\% in the VRD region for the combined technologies scenario. Alternatively, if the objective is to specifically focus on reducing methane production, when net profit in the integrated technologies scenario is set to the baseline by reducing herd size, then methane production per hectare is reduced by a very significant $65-70 \%$. This is largely the result of the herd size decreasing by $30 \%$ when the net profit levels between scenarios are matched.
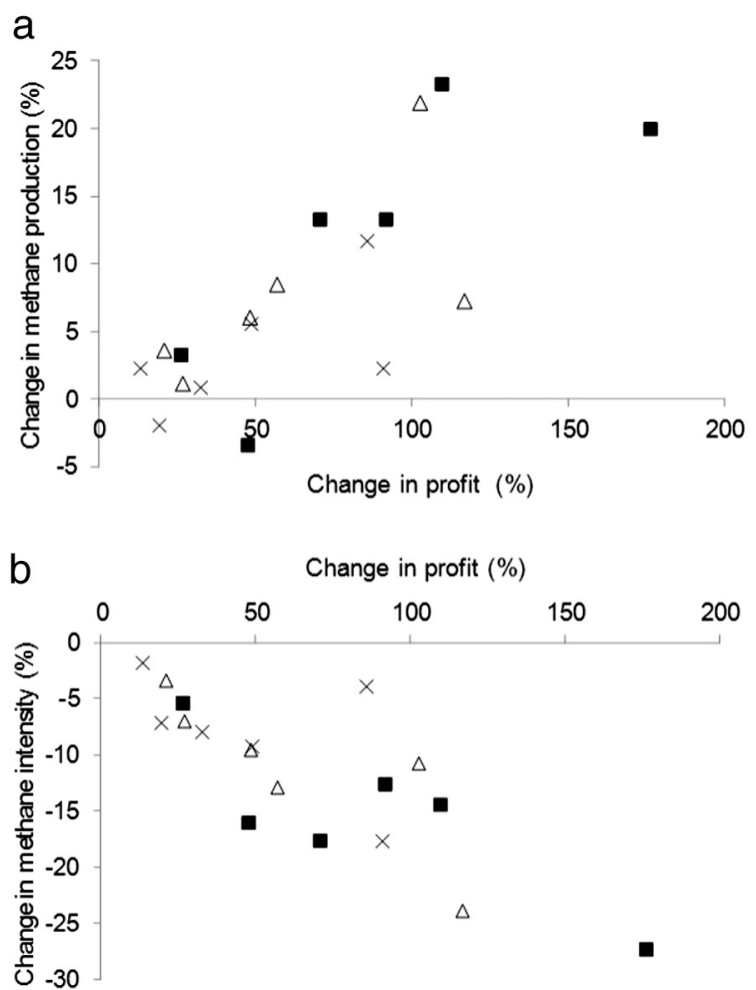

Fig. 5. The relationship between the change in profit and change in methane production across development scenarios for the three study regions. (a) Total methane production, (b) methane intensity. $\times$, south-east Queensland, $\Delta$, northern Queensland, $\mathbf{a}$, Victoria River District. 
Table 7

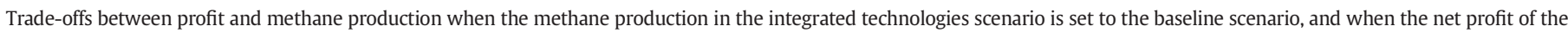
integrated technologies scenario is set to the baseline, for the northern Queensland and Victoria River District case studies.

\begin{tabular}{|c|c|c|c|c|c|}
\hline \multirow[b]{2}{*}{ Region } & \multirow[b]{2}{*}{ Performance measure } & \multicolumn{4}{|l|}{ Scenario } \\
\hline & & Baseline & Integrated technologies & $\begin{array}{l}\text { Integrated technologies with } \\
\text { methane = baseline }\end{array}$ & $\begin{array}{l}\text { Integrated technologies with } \\
\text { profit = baseline }\end{array}$ \\
\hline \multirow[t]{5}{*}{ Northern Queensland } & $\mathrm{AE}$ (adult equivalents) & 2901 & 3184 & 2962 & 2011 \\
\hline & Gross margin/AE (\$) & 125 & 174 & 175 & 177 \\
\hline & Profit (\$/year) & 165,607 & 358,693 & 326,833 & 165,473 \\
\hline & Methane $\left(\mathrm{kg} \mathrm{CO}_{2} \mathrm{e} / \mathrm{ha} /\right.$ year$)$ & 205 & 220 & 205 & 140 \\
\hline & Methane ( $\mathrm{kg} \mathrm{CO} 2 \mathrm{e} / \mathrm{kg}$ beef produced) & 18.7 & 14.3 & 14.2 & 13.7 \\
\hline \multirow[t]{5}{*}{ Victoria River District } & $\mathrm{AE}$ & 18,721 & 23,341 & 19,281 & 12,851 \\
\hline & Gross margin/AE $(\$)$ & 101 & 151 & 151 & 148 \\
\hline & Profit (\$/year) & 912,766 & $2,518,827$ & $1,915,676$ & 912,234 \\
\hline & Methane $\left(\mathrm{kg} \mathrm{CO}_{2} \mathrm{e} / \mathrm{ha} / \mathrm{year}\right)$ & 75 & 90 & 75 & 50 \\
\hline & Methane ( $\mathrm{kg} \mathrm{CO} 2 \mathrm{e} / \mathrm{kg}$ beef produced) & 21.9 & 16.0 & 15.9 & 15.8 \\
\hline
\end{tabular}

\section{Discussion}

Using a new systems model of beef enterprises in tropical Australia, we have demonstrated how a range of interventions to increase productivity of beef herds can lead to substantial improvements in profitability without degrading pasture and land condition. The interventions covered a range of areas of individual animal productivity from genetic gain to rumen function to nutrition and all could provide benefits, especially when used in combination.

The simulation results for the two genetic gain scenarios (improved reproduction and growth efficiency) are consistent with published data based on experiments and data from commercial enterprises. For example, increasing weaning rate by $5 \%$ points gave comparable results to that of Schatz (2011) who found that when average herd reproductive efficiency was increased by about $5 \%$, the estimated gross margins increased by $\$ 6-\$ 8 / \mathrm{AE}$. Larger economic gains have been demonstrated for cases in which more significant improvements in reproductive efficiency are achieved. For example, Burrow et al. (2003) found that by shifting breeds from pure or near pure $B$. indicus to tropical composites (a mix of B. indicus and B. taurus breeds), weaning rates could be increased by 17 percentage points to yield a gain of approximately $\$ 17 / \mathrm{AE}$.

The simulation trial results affirm that herd fertility is a significant profit driver of northern beef enterprises (Burns et al., 2010). Accordingly, considerable effort has gone into improving the reproduction efficiency of the northern beef herd over the last several decades. This particular scenario has been focussed on further improving average conception and weaning rates of breeding herds. Gains in overall reproductive efficiency can also be achieved through: earlier puberty (Fordyce et al., 1994; Fortes et al., 2012); reducing pre-natal, perinatal and post-natal mortality rates, which are currently high (and simulated accordingly in this modelling study) although the causes are not as yet well understood (Burns et al., 2010); and reducing losses from animal disease.

The genetic gains in growth efficiency simulated in this study are within the scope of what can be achieved over 20 years by selecting bulls with high Estimated Breeding Values (EBVs) for 600 day weight (Burrow and Rudder, 1991). Growth rates are moderately heritable (Burrow, 2001, 2012) indicating that there is good opportunity to achieve reasonable production gains through genetic improvement. However, heritability relating to weight is higher than that relating to weight gain, and especially post-weaning (Davis, 1993). There is a risk that selecting for weight will simply result in an increase in the mature body size of animals rather than in growth efficiency, with commensurate increases in feed requirements. Notwithstanding these factors, the simulation results suggest that significant gains in productivity and profitability can be achieved in response to genetic gains in growth efficiency.
The simulated effects of increasing digestibility through improving rumen function were surprisingly large. A considerable research effort has been expended to develop novel technologies to improve the digestive efficiency of ruminants. This has included research on feed additives such as ionophores (e.g. monensin) to reduce methane production (Guan et al., 2006) and improve animal performance from grain diets (Goodrich et al., 1984), although the benefits of this approach for cattle consuming low quality tropical pasture may be negligible (McLennan et al., 1995). Research has also been focussed on altering the rumen ecology in order to improve digestion, although fundamental understanding of rumen processes still limits any significant practical breakthroughs (Klieve, 2009). While the simulation trial results clearly highlight the benefits that increasing energy efficiency may achieve, there are no immediate prospects of a practical breakthrough in technology. As a consequence overcoming nutritional constraints in northern Australia has been focussed on addressing protein and other mineral and trace element deficiencies because these have been the more tractable problems to address.

The addition of legumes to tropical pastures has been demonstrated to greatly improve animal productivity by overcoming seasonal protein deficiencies. The increase in annual liveweight gain of $25-30 \mathrm{~kg} / \mathrm{head}$ simulated in the improved pasture scenario is consistent with results from grazing trials (Coates et al., 1997). Given the large positive impact of this legume-augmentation scenario on productivity and net profit the question is necessarily raised as to why legumes are not more widely used in areas for which suitable species are currently available. High costs and poor reliability of establishment have in the past been put forward by producers as significant constraints to wider adoption (Clements, 1996). Miller et al. (1993) showed that the financial payback period was 8 years if it took five years for the oversown legume pasture to reach full productivity and the Net Present Value was greatly reduced under that scenario compared with reaching full productivity within 1 year.

In considering a possible expansion in the use of oversown legumes, attention must also be given to the potential environmental consequences. For example, stylo (Stylosanthes spp.), which is presently the most successful pasture legume used in northern Australia, is not without potential negative consequences. These largely relate to legume dominance, which can result in soil acidification, reduced cover levels and increased erosion risk, and biodiversity impacts (Noble et al., 2000). Nevertheless, these risks can be managed in part through strategic use of fire, grazing management and targeted fertiliser use (Noble et al., 2000). In the analysis in this study, only the establishment costs were considered and the costs of additional management or inputs to manage legume dominance would need to be considered. 
Another option for overcoming protein deficiency of animals grazing low quality tropical pastures is through protein supplementation. A number of protein meals are commercially available but their cost generally prohibits widespread use. Potential sources of a novel high protein supplement available at low cost could include algal biodiesel residue (Bryant et al., 2012) or on-farm algal protein production (Holman and Malau-Aduli, 2013). The simulated liveweight gains found in this study assuming a cheap algal protein source was available are broadly consistent with experimental data for similar quality protein meals such as cottonseed meal (e.g. Addison et al., 1984), although the gains achieved are somewhat lower than might be predicted by empirical relationships between the amount of protein supplied and the liveweight gain response (McLennan et al., 1995). The lesser response in the simulated liveweight gains (c. $200 \mathrm{~g} /$ day) compared with the expected response from the empirical data sources (c. $300 \mathrm{~g} /$ day) is, in part, likely due to years in the simulation where green pasture was available through the dry season as a result of autumn or winter rainfall. In subtropical south-east Queensland, where the seasonal decline in protein is not as significant as in the northern tropical regions, the projected gains in animal productivity and net profit were considerably lower.

Combining a range of different production technologies and practices rather than focussing effort in one or two particular areas resulted in large increases in productivity and profitability, suggesting these technologies act in a synergistic way. The magnitude of the projected liveweight gain advantages would suggest that for some of the regions in the study, the herd structure and business operation could profitably be changed to finishing turn-off cattle to a heavier weight for slaughter rather than producing lighter animals that are traded in order to be finished in environments with better quality pastures. Given the size of the productivity gains projected for this scenario the number of breeding animals had to be actively reduced to prevent the total herd size from increasing to levels that negatively affected land condition. However, only a relatively small proportion of the gain in profitability could be attributed to the increase in the average herd size - most of it resulted from gains in individual animal productivity. For example, in the northern Queensland case study, when breeding cow numbers were restricted to achieve a herd size that is exactly the same as the baseline (2901 $\mathrm{AE}$ ), average annual net profit was $\$ 330,000$, approximately double that of the baseline. There are many possible combinations of technologies that could be explored and in this study we focussed on a combination that targeted different components of animal production (genetics, rumen digestion, protein).

Introducing new technologies that increase the productivity of extensive beef enterprises can pose a risk to sustainable grazing land management because the productivity gains are often associated with higher animal numbers and degradation of the resource base (Gardener et al., 1990). Associated with this, it is known that rapid rebuilding of herd numbers following a drought can exacerbate land degradation (McKeon et al., 2004) so care needs to be exercised in use of new technologies that increase production. Each of the technologies that were assessed in this study had a tendency to result in the herd size increasing through the duration of the simulation trials. This was in part because the individual animals generally became more productive and their higher average weight contributed to a larger herd size, as measured by adult equivalents. However, the total size of the herds also increased in response to technologies that increased weaning rates. While the pasture improvement scenario of legume oversowing also results in increasing animal productivity and total numbers carried, it does this through an increased total level of pasture productivity (biomass and quality) which also increases the effective carrying capacity of the enterprise. To avoid overstocking and utilisation of pasture increasing beyond sustainable levels, herd numbers in this study were not allowed to increase significantly and if necessary, breeding cow numbers were reduced to ensure this outcome. By adopting this particular herd management strategy, in the simulations land condition could be maintained while at the same time permitting improved financial outcomes.
Given the extensive nature of beef production and the low quality pastures in northern Australia, methane output per unit of product is high, as is methane output per unit of dry matter intake (Charmley et al., 2008). Increasing the intensity of production in beef systems generally increases total methane emissions (White et al., 2010), while lowering methane per $\mathrm{kg}$ of beef produced. However, management decisions can be made along the intensification spectrum as to how much to increase productivity and profitability versus reducing the environmental footprint.

\section{Conclusions}

The principal aim of this study was to assess the production and financial implications for north Australian beef enterprises of a range of technology interventions (development scenarios) that were capable of lifting individual animal and herd productivity. In pursuing this objective it was necessary to develop a beef systems model capable of simulating livestock production at the enterprise level, including reproduction, growth and mortality based on energy and protein supply from natural pastures as well as augmentation of the diet through supplements and improved pastures and forage crops.

Testing of development scenarios suggested that the individual application of technologies related to improving the feed-base or its utilisation in the animal may offer substantial gains in productivity and profitability, while the gains associated with genetic improvements in reproduction and growth of cattle were less but still significant. However, the simultaneous implementation of multiple technologies that provide benefits to different aspects of individual animal productivity resulted in the greatest increases in cattle productivity and enterprise profitability. There can be adoption challenges to implementing new technologies in farming systems so promoting the use of combinations of technologies in a systems approach will require a concerted effort in best practice management.

\section{Acknowledgements}

We thank Meat and Livestock Australia (B.BSC.0107) and the CSIRO Agriculture Flagship for funding this study. The support and guidance of the project steering committee (Peter Carberry, Felice Driver, Wayne Hall, Peter Johnston, Terry Longhurst, Neil MacDonald, Brad McCormick and Ralph Shannon) was much appreciated. Members of the regional beef research committees across northern Australia made valuable suggestions for development options to be considered in the simulations. Roger Landsberg, Michael Lyons and Steve Petty provided feedback on the model outputs and provided helpful suggestions for simulating regional beef enterprises.

\section{Appendix A}

\section{A.1. Model overview}

The Northern Australia Beef Systems Analyser (NABSA) model is a whole-farm-scale dynamic simulation model that mimics the response over time of a beef cattle enterprise that is operating under a specified array of development options. The NABSA model operates within the Microsoft Excel ${ }^{\circledR}$ environment and uses a monthly time step. The model integrates livestock, pasture and crop production with labour and land resource requirements and availability, accounts for revenue and cost streams, and provides estimates of the expected environmental consequences of various management options (Fig. A.1). The responses include production, environmental and economic dimensions, which are generated as output for each year of a simulation trial and as trial averages. The NABSA model is broadly based on an approach that was previously developed to simulate the performance of smallholder crop-livestock systems in developing countries (Lisson et al., 2010). 


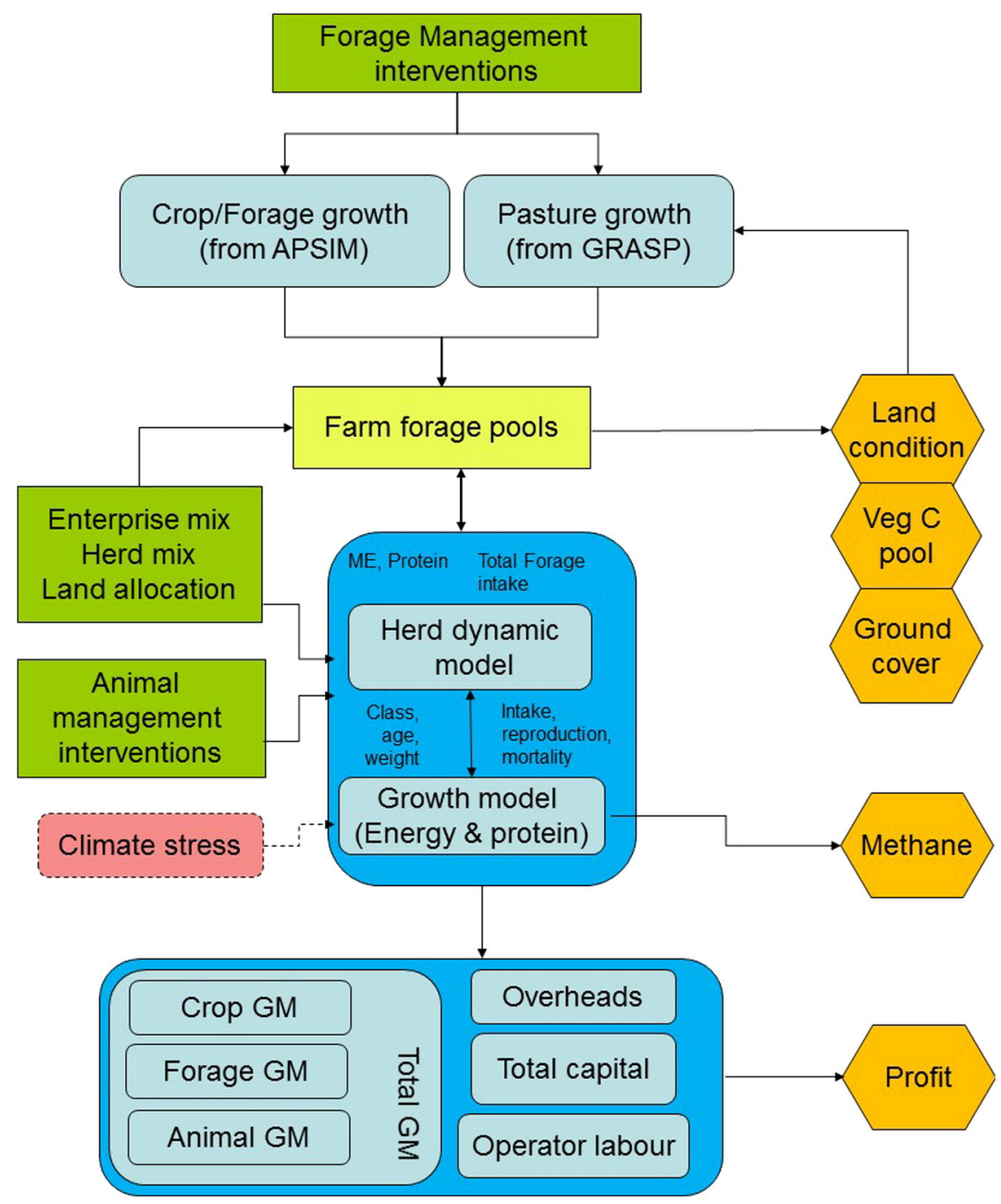

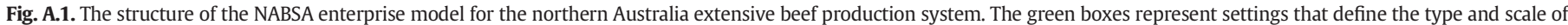

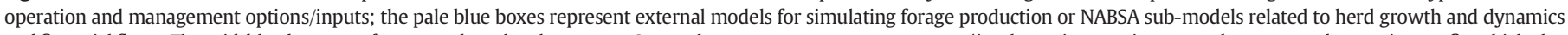

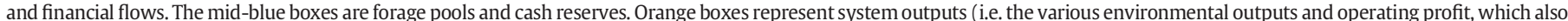
includes animal productivity outputs). (For interpretation of the references to colour in this figure legend, the reader is referred to the web version of this article.)

The type of beef enterprise on which simulation trials are run (e.g. breeding and finishing, breeding only, steer finishing, trading) is defined by the user based on the property size, the area that is used for grazing, soil and vegetation type, starting land condition and approximate herd size. The age and sex class structure of the beef herd and the main class and age/condition of turn-off animals are stipulated based on a herd dynamics approach previously developed by MacLeod et al. (2004) to track changes in the number of animals in different age and sex cohorts over time. Herd size is largely determined by the user through setting the maximum breeder number and this interacts with herd dynamics (initial herd structure, reproduction and growth rates and target weights of turn-off animals) to influence actual herd size. Rules are put in place for sale and purchase of animals to achieve the target breeder number. Other input parameters associated with the herd operations include labour supply and demand, direct husbandry and marketing costs (transport, veterinary, fuel, supplementary feeding etc), overhead costs, prices per kilogram of liveweight for different animal classes, rules for sale of animals and feeding and disposal of animals when forage becomes limiting.

\section{A.2. Forage production and quality}

Once a particular enterprise has been defined and structured, a simulation trial (single model run) is commenced using an historical climate file for the relevant study site in order to capture the interand intra-seasonal growth patterns of the available forages that supply the animals with nutrients. Forage availability data come from external sources (e.g., stand-alone forage growth simulation models) and are imported into a pasture database that the NABSA model accesses to acquire monthly pasture or forage crop growth. In the present study forage growth of native pastures was simulated using the GRASP pasture simulation model (McKeon et al., 2000), which is a process based model that uses daily climate, soil water holding capacity and soil nitrogen to drive pasture growth. Given that the objective of this study was to explore a range of productivity improvement options it was also considered important to be able to explore other forage options, including sown pastures (e.g. Bambatsi panic; Panicum coloratum) and forage crops. The APSIM crop growth simulation model (Keating et al., 2003) was used to simulate forage crop growth using the same daily historical climate files as those used to generate the GRASP native pasture growth data. The APSIM crop yield data is imported into the NABSA model in the same way as the GRASP output.

Forage quality is a strong driver of animal growth and reproduction and is a particularly important issue in northern Australia due to the seasonal protein and energy deficiency that is typically associated with tropical grasses (McLean et al., 1983). The quality of forage from new pasture growth, the decay rate through the season and the 
minimum quality can all be stipulated within the model. Data on these pasture quality parameters were obtained from Near Infrared Spectroscopy (NIRS) analysis of cattle dung from free ranging cattle in different parts of northern Australia (e.g. Coates and Dixon, 2008). Fig. A.2 shows NIRS data for dietary crude protein from a grazing experiment in northern Queensland (Wambiana grazing trial, data supplied by Peter O'Reagain, Queensland Department of Agriculture, Fisheries and Forestry). This pattern in seasonal forage quality is typical of tropical grass pastures in northern Australia.

The model combines both the growth of pasture and its changing quality through the year in twelve monthly forage pools. New pasture growth enters Pool 1 and then declines in quality month by month (Fig. A.3). New forage that is not consumed within a month carries over to the next month but with a user defined detachment factor that results in pasture that is not consumed gradually disappearing from the forage pools. This detached pasture becomes litter which gradually breaks down through time. The model selects fodder from pools 1-12 in that order, if forage is available and subject to user defined limits on use from each pool. The pools of green and dry forage (Pools 1-3 are set as green) are tracked and these are used to drive the percentage of green in the diet of cattle. It is well known that new green growth is not always fully available to animals because it is usually growing within mature pasture sward and animals will consume both new growth and mature pasture. The nature of the relationship between green forage in the pasture and that in the diet has been established for tropical grass pastures in northern Australia (Hendricksen et al., 1982) and the shape of this relationship can be user-modified.

This approach of using monthly forage pools provides a realistic representation of forage quality for the different regional climates and land types across northern Australia. For example, in central Queensland there can regularly be new forage growth (Pool 1) in six months of the year, while in the monsoon tropics the combination of short seasons and poorer soils typically results in new forage growth occurring in only three or four months of the year.

Additional high quality forage from special purpose forage crops (in this case simulated with the APSIM model) can be strategically made available to particular classes of animals (e.g., young growing animals, first calving heifers) to allow enhanced growth or support improved reproductive performance. The quantity and quality of the forage crop is provided on a monthly time-step as Forage Pool 13 and unlike native pasture the quality for each month is provided as input rather than proceeding through the decay and detachment processes.

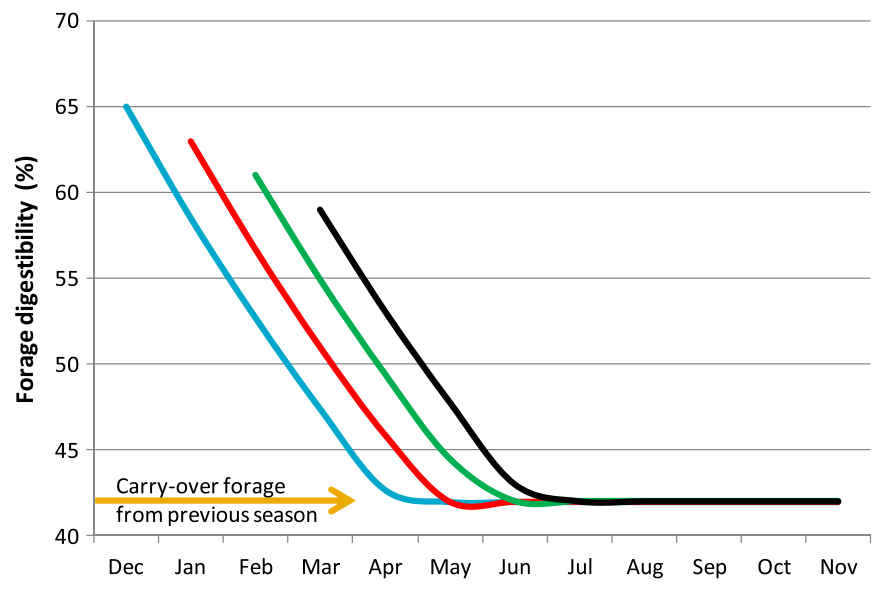

Fig. A.3. Conceptual representation of how forage quality declines through the year after entering as high quality forage in the month of its growth. The blue line represents high quality growth produced at the start of the wet season, which then declines in quality through the year; the red line represents new growth in January that is slightly lower quality than that produced in December, which then declines in quality through the year: the green and black lines follow a similar pattern, with, in this representation, no new growth occurring after April. The orange line at the bottom of the figure represents old, low quality forage carrying over from the previous growing season. (For interpretation of the references to colour in this figure legend, the reader is referred to the web version of this article.)

\section{A.3. Animal growth}

Critical determinants of animal growth are feed intake and quality of the diet, which are especially important in these nutrient limited tropical pasture systems. Simulation of animal growth from birth to turn-off is based on the available energy and protein supplied by forages and feed supplements using standard relationships for the nutrient requirements of domesticated ruminants (CSIRO, 2007). The NABSA incorporates the first model of cattle growth for northern Australian forage conditions that takes this particular approach. Previous simulation models have employed relatively simple regression relationships to simulate animal growth (e.g. the percentage of pasture green days, pasture utilisation rate and animal growth; McKeon et al., 2000) or have not incorporated the appropriate diet selection and animal growth relationships for tropical pastures.

Individual animal intake is determined by the weight of animals relative to a standard reference weight (the expected mature weight of an

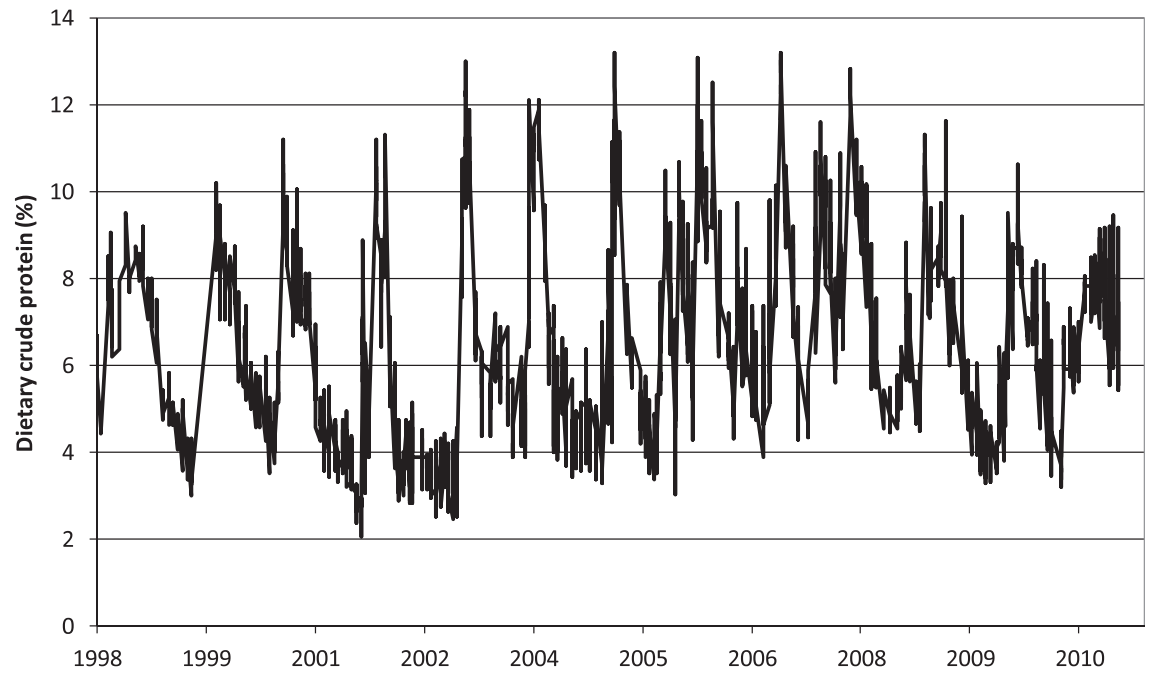

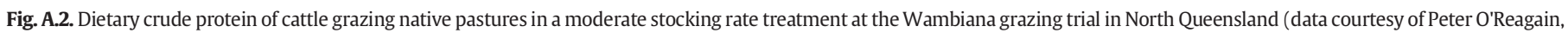
Queensland Department of Agriculture and Fisheries, Charters Towers). 
animal). Conversion of nutrient intake into growth is based directly on the relationships and equations provided in the Nutrient Requirements of Domesticated Ruminants (CSIRO, 2007). Calf growth is determined by the available milk supply which, in turn, depends on the nutritional conditions of the lactating cows. Time of weaning of suckling calves can be varied within the model, which allows testing of early weaning scenarios. Compensatory growth is not explicitly represented in the model which means late dry season losses and early wet season gains in body weight are both underestimated, with the assumption that these gains and losses will essentially offset each other.

The model can simulate situations where low forage availability (e.g. due to poor seasons or overstocking) limits individual animal intake (Fig. A.4.). The empirical data available for generating these relationships in tropical pastures is sparse e.g., Stobbs (1977).

\section{A.4. Reproduction and mortality}

Body condition score is a major factor determining reproductive success in females of a breeding age in the extensive grazing systems of northern Australia (McGowan et al., 2014). In NABSA, conception is determined by the weight of cows relative to its reference weight, which is an effective surrogate for body condition score (Fig. A.5). The shape of the relationship between body weight in relation to reference weight and conception can be altered and different relationships are used for heifers and more mature cows. This relationship is based on research results taken from a number of studies across northern Australia and is consistent with relationships that have been recently published that are based on large datasets also drawn from across northern Australia (Mayer et al., 2012; McGowan et al., 2014). This approach yields realistic conception and weaning rates, including the lower pregnancy rates that are typically observed in younger cows in nutritionally stressful environments (MLA, 2007; Schatz, 2012; McGowan et al., 2014).

Peri-natal and post-natal mortality rates in breeding cattle in northern Australia can be significant but there is no clear major factor driving this mortality (McGowan et al., 2014). Consequently in the model, periand post-natal mortality rates are a single user-defined parameter, but based on the data of McGowan et al. (2014) this is likely to be in the range of 5 to $16 \%$.

Cow mortality rates can also be significant (Henderson et al., 2013; McGowan et al., 2014) and in the model cow mortality rate is determined by actual body weight relative to the standard reference weight for that class of animal (Fig. A.6.). In addition, a baseline mortality rate

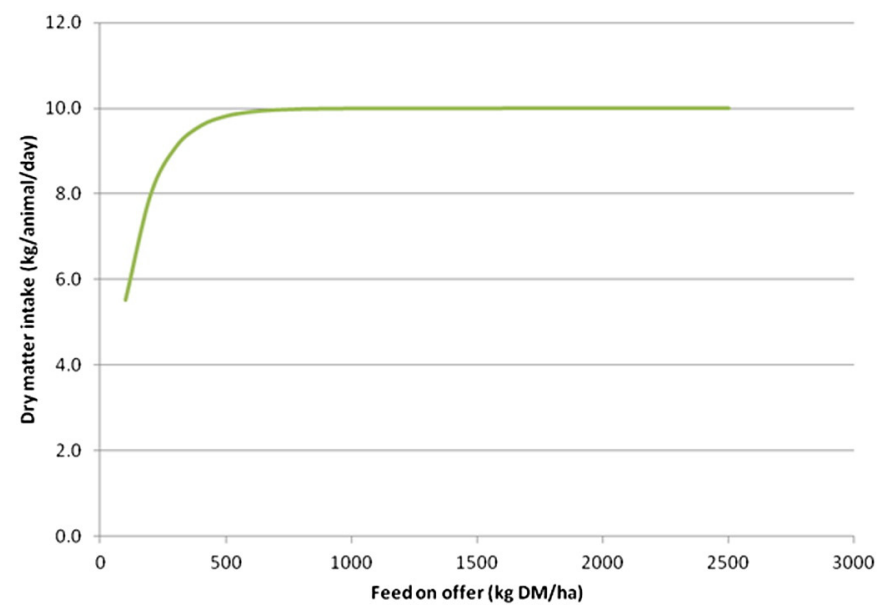

Fig. A.4. An example of the relationship between forage availability and potential feed intake in extensive native pasture conditions in the tropics where maximum potential feed intake is $10 \mathrm{~kg}$ dry matter/day. The relationship is described by the equation: dry matter intake $=\mathrm{a}\left(1-\mathrm{e}^{-\mathrm{b} \text {.feed on offer }}\right)$, where $\mathrm{a}$ is the asymptote for maximum potential feed intake and $b$ is the coefficient for the shape of the curve (in this case 10 and 0.006 , respectively).

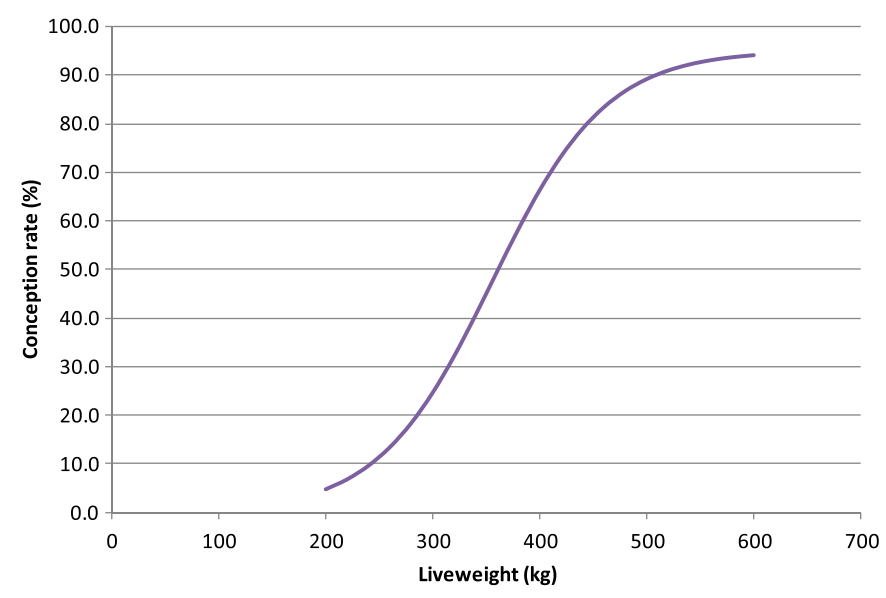

Fig. A.5. Example of a relationship between cow liveweight and conception for a mature cow with a standard reference weight of $520 \mathrm{~kg}$. The shape of the relationship is described by the equation:

Conception rate $(\%)=\mathrm{A} /(1+\operatorname{Exp}(\mathrm{k} *$ cow wt actual/cow reference wt $+\mathrm{C}))$, where $\mathrm{A}=$ asymptote maximum conception rate, $\mathrm{k}=$ coefficient function for shape of the curve, and $C=$ constant. Cow wt actual is cow weight at conception. Values for this example are $\mathrm{A}=95, \mathrm{k}=-9.8, \mathrm{C}=6.7$.

based on regionally sourced information can be set that applies across all animal classes in the herd.

\section{A.5. Supplementation and drought feeding}

NABSA allows for additional energy and protein to be made available to animals via supplements and/or hay to maintain or improve animal condition during seasonal nutritional deficits or drought. A range of different supplements or hay can be fed (e.g. salt and urea blocks, urea:molasses mixes, cottonseed meal, grain, hay) in different months of the year to different animal classes, and more than one supplement can be used at the same time if required.

Although phosphorus deficiency is a characteristic of many soils across northern Australia (Jackson et al., 2012), its effects on animal productivity are not directly represented in the current version of the animal production model. Animals are assumed to have sufficient phosphorus supply and in areas where phosphorus is known to be deficient it can be included as a supplement to reflect the increased costs of production.

\section{A.6. Enterprise economics}

Enterprise economic outcomes (except for taxation) are simulated by assessing the revenues from animal turnoff against the direct costs of production (animal veterinary costs, transport, marketing costs, commission, etc.) to generate the total enterprise gross margin. In addition, enterprise overhead costs, general labour and interest paid on outstanding debts are calculated to generate net profits. The level of cash balance on hand or the opening debt is specified for the first year of a simulation trial and this accumulates or is drawn down through the trial according to the projections of annual cash surpluses and deficits. Capital costs associated with any development scenario (e.g. plant and machinery, irrigation or stock handling infrastructure) are included as a debt, but there is no annual depreciation charge included in overhead costs.

\section{A.7. Natural resource condition}

It is possible to simulate some key resource condition outcomes for modelled scenarios. The pasture utilisation rate (an estimate of the proportion of the total pasture growth that is consumed by animals) determines land condition, defined on the basis of the basal area of 


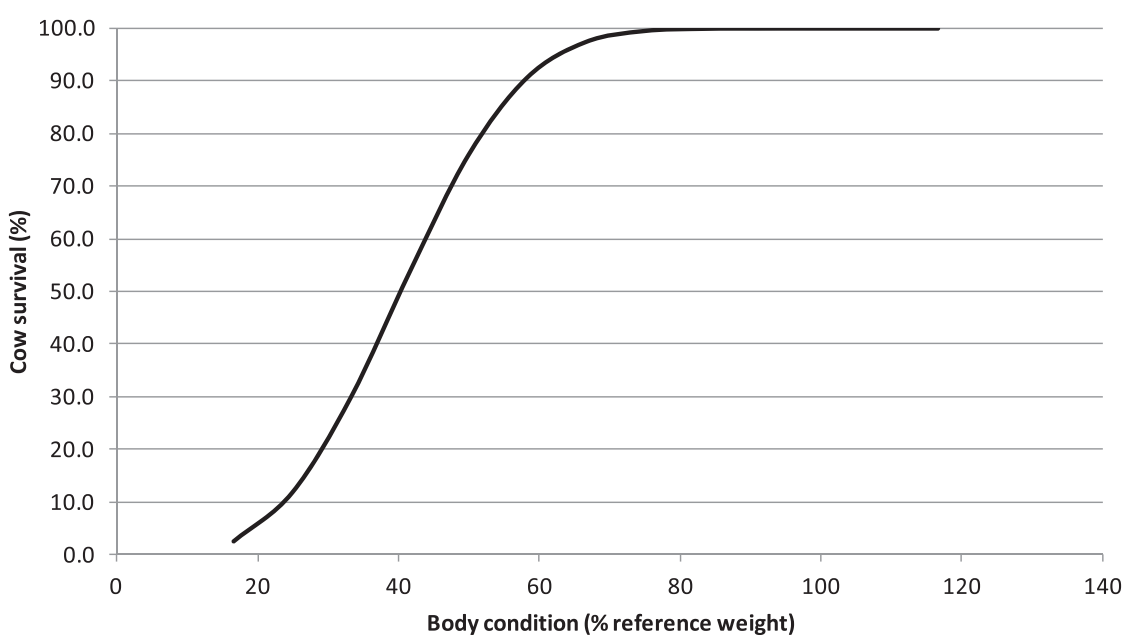

Fig. A.6. The relationship between body condition (liveweight as a percentage of reference weight) and cow survival rate across age classes.

desirable perennial grasses, with high utilisation rates driving down perennial grass basal area and hence land condition. The index ranges from 0 to 11 with degraded land having an index of 11 and pristine land having an index of 0 . Sustainably managed pastures generate land condition indices in the range of 1 to 5 . There is a dynamic link between land condition and pasture growth simulated in the GRASP model. For example, if land condition declines due to high utilisation the NABSA model selects the next year's pasture growth from GRASP based on the reduced land condition. If high utilisation rates are maintained over a number of years there is a degradation spiral downwards with reduced pasture growth forcing up utilisation rates if stock numbers are not modified. How land condition improves or deteriorates in response to the pasture utilisation rate can be altered for different climate-pasture systems. Qualitative indices that integrate the effects of livestock production across a range of resource condition criteria are also produced by the model. The approach used to produce these indices builds on earlier work for extensive beef enterprises in northern Australia (MacLeod and Mclvor, 2008).

\section{A.8. Methane production}

Methane production from beef cattle grazing pastures is closely related to dry matter intake (Kennedy and Charmley, 2012). As the NABSA model predicts the dry matter intake of cattle, a simple regression relationship has been used to derive methane production. The actual relationship was initially developed by Kurihara et al. (1999) to estimate methane production for tropical pastures, and amended by Hunter (2007), and is presently also used in Australia's inventory of greenhouse gas emissions (National Greenhouse Gas Inventory Committee, 2006). This equation (Hunter, 2007) is:

Methane $(\mathrm{g} /$ day $)=35.16 *$ intake -34.8 .

\section{A.9. Model limitations}

Although the NABSA model was developed to test a diverse range of potential scenarios at the enterprise scale, the current version of the model cannot capture the operational diversity and complexities of actual beef enterprises in their entirety. In common with any model of a complex system, it has recognised limitations and requires a number of simplifying assumptions, including the following:

- Diseases are not explicitly represented in the animal production model, but recognised management practices to minimise their effect are included in the specification of veterinary costs (e.g. vaccines).
Diseases can also be indirectly represented in productivity through altering conception curves or growth coefficients or mortality rates.

- There is no variation among individuals within a given class of animals. All of the animals within a class are subject to the same process rates (e.g. grow at the same rate, consume supplement at the same rate, conceive at the same time).

- The model has no capacity to directly simulate the performance of separate paddocks, and does not address spatial issues such as uneven grazing distribution and its effect on intake, diet quality and animal production. The model does allow for different land types to be specified based on soil and vegetation characteristics, which can be approximated to be representative of a number of paddocks (although in this study it has been assumed that a single land type exists on a property).

- No additional capital costs are included in the model beyond those that are specifically related to a particular development scenario. General maintenance and repair costs are included as overhead costs but imputed costs for depreciation and replacement of capital items are not included.

\section{References}

ABARES, 2014. Agricultural Commodities June quarter 2014. Australian Bureau of Agricultural and Resource Economics and Sciences, Canberra.

Addison, K.B., Cameron, D.G., Blight, G.W., 1984. Biuret, sorghum and cottonseed meal as supplements for weaner cattle grazing native pastures in sub coastal south east Queensland. Trop. Grassl. 18, 113-120.

Ash, A.J., McIvor, J.G., Mott, J.J., Andrew, M.H., 1997. Building grass castles: integrating ecology and management of Australia's tropical tallgrass rangelands. Rangel. J. 19, 123-144.

Ashfield, A., Crosson, P., Wallace, M., 2013. Simulation modelling of temperate grassland based dairy calf to beef production systems. Agric. Syst. 115, 41-50.

Bell, L.W., Hayes, R.C., Pembleton, K.G., Waters, C.M., 2014. Opportunities and challenges in Australian grasslands: pathways to achieve future sustainability and productivity imperatives. Crop Pasture Sci. 65, 489-507.

Bortolussi, G., Mclvor, J.G., Hodgkinson, J.J., Coffey, S.G., Holmes, C.R., 2005. The northern Australian beef industry, a snapshot. 1. Regional enterprise activity and structure. Aust. J. Exp. Agric. 45, 1057-1073.

Bryant, H.L., Gogichaishvili, I., Anderson, D., Richardson, J.W., Sawyer, J., Wickersham, T., Drewery, M.L., 2012. The value of post-extracted algae residue. Algal Res. 1, 185-193.

Burns, B.M., Fordyce, G., Holroyd, R.G., 2010. A review of factors that impact on the capacity of beef cattle females to conceive, maintain a pregnancy and wean a calf - implications for reproductive efficiency in northern Australia. Anim. Reprod. Sci. 122, 1-22.

Burrow, H.M., 2001. Variances and covariances between productive and adaptive traits and temperament in a composite breed of tropical beef cattle. Livest. Prod. Sci. 70, 213-233.

Burrow, H.M., 2012. Importance of Adaptation and Genotype $\times$ Environment Interactions in Tropical Beef Breeding Systems Available on CJO 2012. http://dx.doi.org/10.1017/ S175173111200002X. 
Burrow, H.M., Rudder, T.H., 1991. Increased profit through selection of zebu crossbred cattle for growth rate in the tropics. AAABG 9th Conference, 24-27 June 1991, pp. 186-189.

Burrow, H.M., Griffith, G.R., Barwick, S.A., Holmes, W.E., 2003. Where to from Brahmans in the northern Australian herd? Maintaining the economic benefit of earlier infusions of Bos indicus. Proceedings of the Australian Association of Animal Breeding and Genetics 15 pp. 294-297.

Cacho, O.J., Bywater, A.C., Dillon, J.L., 1999. Assessment of production risk in grazing models. Agric. Syst. 60, 87-98.

Charmley, E., Stephens, M.L., Kennedy, P.M., 2008. Predicting livestock productivity and methane emissions in northern Australia: development of a bio-economic modelling approach. Aust. J. Exp. Agric. 48, 109-113.

Clark, D.A., 2013. The changing nature of farm systems research. Proc. N. Z. Soc. Anim. Prod. 73, 54-64.

Clements, R.J., 1996. Pastures for prosperity. 3. The future for new tropical pasture plants. Trop. Grassl. 30, 31-46.

Coates, D.B., Dixon, R.M., 2008. Faecal near infrared reflectance spectroscopy measurements of diet quality and responses to $\mathrm{N}$ supplements by cattle grazing Bothriochloa pertusa pastures. Aust. J. Exp. Agric. 48, 829-834.

Coates, D.B., Miller, C.P., Hendricksen, R.E., Jones, R.J., 1997. Stability and productivity of Stylosanthes pastures in Australia. II. Animal production from Stylosanthes pastures. Trop. Grassl. 31, 494-502.

Cook, G.D., Williams, R.J., Stokes, C.J., Hutley, L.B., Ash, A.J., Richards, A.E., 2010. Managing sources and sinks of greenhouse gases in Australia's rangelands and tropical savannas. Rangel. Ecol. Manag. 63, 137-146.

Crosson, P., O'Kiely, P., O'Mara, F.P., Wallace, M., 2006. The development of a mathematical model to investigate Irish beef production systems. Agric. Syst. 89, 349-370.

CSIRO, 2007. Nutrient Requirements of Domesticated Ruminants. Primary Industries Standing Committee on Agriculture. CSIRO Publishing, Melbourne (296 pp.).

Davis, G.P., 1993. Genetic parameters for tropical beef cattle in northern Australia: a review. Aust. J. Agric. Res. 44, 179-198.

Farina, S.R., Alford, A., Garcia, S.C., Fulkerson, W.J., 2013. An Integrated Assessment of Business Risk for Pasture-Based Dairy Farm Systems Intensification.

Foran, B.D., Stafford Smith, D.M., Niethe, G., Stockwell, T., Michell, V., 1990. A comparison of development options on a northern Australian beef property. Agric. Syst. 34, 77-102. http://dx.doi.org/10.1016/0308-521X(90)90095-8.

Fordyce, G., Entwistle, K.W., Fitzpatrick, L.A., 1994. Developing cost effective strategies for improved fertility in Bos indicus cross cattle. Final Report, Project NAP2:DAQ.062/ UNQ.009. Meat Research Corporation, Sydney.

Fortes, M.R.S., Lehnert, S.A., Bolormaa, S., Reich, C., Fordyce, G., Corbet, N.J., Whan, V., Hawken, R.J., Reverter, A., 2012. Finding genes for economically important traits: Brahman cattle puberty. Anim. Prod. Sci. 52, 143-150.

Gardener, C.J., Mclvor, J.G., Williams, J., 1990. Dry tropical rangelands: solving one problem and creating another. Proc. Ecol. Soc. Aust. 16, 279-286.

Gleeson, T., Martin, P., Mifsud, C., 2012. Northern Australian beef industry: Assessment of risks and opportunities. ABARES Report to Client Prepared for the Northern Australia Ministerial Forum, Canberra (May 2012. CC BY 3.0).

Goodrich, R.D., Garrett, J.E., Gast, D.R., Kirick, M.A., Larson, D.A., Mieske, J.C., 1984. Influence of monensin on the performance of cattle. J. Anim. Sci. 58, 1484-1498.

Guan, H., Wittenberg, K.M., Ominkski, K.H., Krause, D.O., 2006. Efficacy of ionophores in cattle diets for mitigation of enteric methane. J. Anim. Sci. 18, 1896-1906.

Henderson, A., Perkins, N., Banney, S., 2013. Determining property-level rates of breeder cow mortality in northern Australia. Final Report Project B.NBP.0664. Meat \& Livestock Australia Limited, North Sydney. ISBN: 9781741919851.

Hendricksen, R.E., Rickert, K.G., Ash, A.J., McKeon, G.M., 1982. Simulation of production variability from native pastures in south-eastern Queensland. Beef production model. Proc. Aust. Soc. Anim. Prod. 14, 204-208.

Holman, B.W.B., Malau-Aduli, A.E.O., 2013. Spirulina as a livestock supplement and animal feed. J. Anim. Physiol. Anim. Nutr. 97, 615-623.

Holmes, W.E., 2011. Representative Herd Templates for Northern Australia V1.00 - Data Files for Breedcow and Dynama Herd Budgeting Software, Beef CRC, DEEDI (Qld), DAFWA and DRDPIF\&R (NT) viewed on 21 April 2103 at. http://www.daff.qld.gov. au/16_20534.htm.

Hunt, L.P., Mclvor, J.G., Grice, A.C., Bray, S.G., 2014. Principles and guidelines for managing cattle grazing in the grazing lands of northern Australia: stocking rates, pasture resting, prescribed fire, paddock size and water points - a review. Rangel. J. 36, $105-120$.

Hunter, R.A., 2007. Methane production by cattle in the tropics. Br. J. Nutr. 98, 657.

Jackson, D., Rolfe, J., English, B., Holmes, W., Matthews, R., 2012. Phosphorus Management of Cattle in Northern Australia. Meat and Livestock Australia Ltd, Sydney.

Johnston, D.J., Barwick, S.A., Fordyce, G., Holroyd, R.G., Williams, P.J., Corbet, R.J., Grant, T., 2014. Genetics of early and lifetime annual reproductive performance in cows of two tropical beef genotypes in northern Australia. Anim. Prod. Sci. $54,1-15$.

Keating, B.A., Carberry, P.C., Hammer, G.L., Probert, M.E., Robertson, M.J., Holzworth, D. Huth, N.I., Hargreaves, J.N.G., Meinke, H., Hochman, Z., McLean, G., Verburg, K., Snow, V., Dimes, J.P., Silburn, M., Wang, E., Brown, S., Bristow, K.L., Asseng, S., Chapman, S., McCown, R.L., Freebairn, D.M., Smith, C.J., 2003. An overview of APSIM, A model designed for farming systems simulation. Eur. J. Agron. 18, 267-288.

Kennedy, P.M., Charmley, E., 2012. Methane yields from Brahman cattle fed tropical grasses and legumes. Anim. Prod. Sci. 52, 225-239.

Klieve, A.V., 2009. Kangaroo bacteria - increasing productivity and reducing emissions of the greenhouse gas methane. Final report to Meat and Livestock Australia on project NBP.354.
Kurihara, M., Magner, T., Hunter, R.A., McCrabb, G.J., 1999. Methane production and energy partition of cattle in the tropics. Br. J. Nutr. 81, 227-334.

Lisson, S., MacLeod, N., McDonald, C., Corfield, J., Pengelly, B., Wirajaswadi, L., Rahman, R. Bahar, S., Padjung, R., Razak, N., Puspadi, K., Dahlanuddin, Sutaryono, Y., Saenong, S., Panjaitan, T., Hadiawati, L., Ash, A., Brennan, L., 2010. A participatory, farming systems approach to improving Bali cattle production in the smallholder crop-livestock systems of Eastern Indonesia. Agric. Syst. 103, 486-497.

MacLeod, N.D., Mclvor, J.G., 2008. Quantifying production-environment tradeoffs for grazing land management - a case example from the Australian rangelands. Ecol. Econ. 65, 488-497.

MacLeod, N.D., Ash, A.J., McIvor, J.G., 2004. An economic assessment of the impact of grazing land condition on livestock performance in tropical woodlands. Rangel. J. 26, 49-71.

MacLeod, N.D., Scanlan, J.C., Whish, G.L., Pahl, L.I., Cowley, R.A., 2011. Application of bioeconomic simulation models for addressing sustainable land management issues for northern Australia. 19th International Congress on Modelling and Simulation, Perth, pp. 801-807.

Mayer, D.G., McKeon, G.M., Moore, A.D., 2012. Prediction of mortality and conception rates of beef breeding cattle in northern Australia. Anim. Prod. Sci. 52, 329-337. http://dx.doi.org/10.1071/AN11204.

McCosker, T., McLean, D., Holmes, P., 2010. Northern beef situation analysis 2009. Project Report B.NBP.0518. Meat and Livestock Australia.

McCown, R.L., 1981. The climatic potential for beef cattle production in tropical Australia: Part I - simulating the annual cycle of liveweight change. Agric. Syst. 6, 303-317.

McGowan, M., Fordyce, G., O'Rourke, P., Barnes, T., Morton, J., Menzies, D., Jephcott, S., McCosker, K., Smith, D., Perkins, N., Marquart, L., Newsome, T., Burns, B., 2014. Northern Australian beef fertility project: CashCow. Final Report Project B.NBP.0382. Meat \& Livestock Australia Limited, North Sydney. ISBN: 9781925045840

McIvor, J.G., Gardener, C.J., 1995. Pasture management in semi-arid tropical woodlands: effects on herbage yields and botanical composition. Aust. J. Exp. Agric. 35, 705-715

Mclvor, J.G., Monypenny, R., 1995. Evaluation of pasture management-systems for beefproduction in the semiarid tropics - model development. Agric. Syst. 49, 45-67. http://dx.doi.org/10.1016/0308-521X(94)00031-L.

McKeon, G., Ash, A., Hall, W., Stafford Smith, M., 2000. Simulation of grazing strategies for beef production in north-east Queensland. In: Hammer, G.L., Nicholls, N., Mitchell, C. (Eds.), Applications of Seasonal Climate Forecasting in Agricultural and Natural Ecosystems. Kluwer Academic Publishers, The Netherlands, pp. 227-252.

McKeon, G.M., Hall, W.B., Henry, B.K., Stone, G.S., Watson, I.W., 2004. Pasture degradation and recovery in Australia's rangelands: learning from history. Queensland Department of Natural Resources. Mines and Energy, Brisbane.

McLean, R.W., McCown, R.L., Little, D.A., Winter, W.H., Dance, R.A., 1983. Analysis of cattle liveweight changes on tropical grass pasture during the dry and early we seasons in northern Australia. 1. The nature of weight changes. J. Agric. Sci. (Camb.) 101, 17-24.

McLennan, S.R., Poppi, D.P., Gulbransen, B., 1995. Supplementation to increase growth rates of cattle in the tropics-protein or energy. Proceedings of Recent Advances in Animal Nutrition, University of New England, Armidale, NSW, July 1995.

McSweeney, C.S., Dalrymple, B.P., Gobius, K.S., Kennedy, P.M., Krause, D.O., Mackie, R.I., Xue, G.P., 1999. The application of rumen biotechnology to improve the nutritive value of fibrous feedstuffs: pre- and post-ingestion. Livest. Prod. Sci. 59 265-283.

Meat and Livestock Australia (MLA), 2007. Beef Cattle Nutrition: An Introduction to the Essentials. Meat and Livestock Australia, North Sydney.

Miller, J.P., Taylor, R.A., Quirk, M.F., 1993. Tropical pasture establishment. 8. Management of establishing pastures. Trop. Grassl. 27, 344-348.

National Greenhouse Gas Inventory Committee, 2006. Australian Methodology for the Estimation of Greenhouse Gas Emissions and Sinks 2004: Agriculture. Department of Environment and Heritage, Canberra.

Noble, A.D., Orr, D.M., Middleton, C.H., Rogers, L.G., 2000. Legumes in native pasture asset or liability? A case history with stylo. Trop. Grassl. 34, 199-206.

Poppi, D.P., McLennan, S.R., 2010. Nutritional research to meet future challenges. Anim. Prod. Sci. 50, 329-338. http://dx.doi.org/10.1071/AN09230.

Puig, C.J., Greiner, R., Huchery, C., Perkins, I., Bowen, L., Collier, N., Garnett, S.T., 2011. Beyond cattle: potential futures of the pastoral industry in the Northern Territory. Rangel. J. 33 181-194.

Scanlan, J.C., McKeon, G.M., Day, K.A., Mott, J.J., Hinton, A.W., 1994. Estimating safe carrying capacities in extensive cattle grazing properties within tropical semi-arid woodlands of north-eastern Australia. Rangel. J. 16, 64-76. http://dx.doi.org/10.1071/ RJ9940064.

Schatz, T.J., 2011. Understanding and Improving Heifer Fertility in Northern Australia Masters by Research thesis. Charles Darwin University.

Schatz, T., 2012. Heifer Management in Northern Beef Herds. In: Partridge, I. (Ed.), Meat and Livestock Australia, North Sydney.

Stobbs, T.H., 1977. Short-term effects of herbage production, milk composition allowance on milk and grazing time of cows grazing nitrogen-fertilized tropical grass pasture. Aust. J. Exp. Agric. 17, 892-898.

Stockdale, M., Huey, A.M., Dray, R., Holmes, P., Smith, P.C., 2012. Kimberley and Pilbara RD\&E program: phase 1. Project Report B.NBP.0628. Meat and Livestock Australia.

Teague, W.R., Foy, J.K., 2002. Validation of SPUR2.4 rangeland simulation model using a cow-calf field experiment. Agric. Syst. 74, 287-302. http://dx.doi.org/10.1016/ S0308-521X(01)00105-6.

Tess, M.W., Kolstad, B.W., 2000. Simulation of cow-calf production systems in arrange environment. I. Model development. J. Anim. Sci. 78, 1159-1169. 
Thompson, T., Martin, P., 2014. Australian beef: financial performance of beef cattle producing farms, 2011-12 to 2013-14. Research Report 14.7. Australian Bureau of Agricultural and Resource Economics and Sciences, Canberra.

Walsh, D., Cowley, R.A., 2011. Looking back in time: can safe pasture utilisation rates be determined using commercial paddock data in the Northern Territory? Rangel. J. 33, 131-142. http://dx.doi.org/10.1071/RJ11003.
White, T.A., Snow, V.O., King, W. McG, 2010. Intensification of New Zealand beef farming systems. Agric. Syst. 103, 21-35.

Wolcott, M.L., Johnston, D.J., Barwick, S.A., 2014. Genetic relationships of female reproduction with growth, body composition, maternal weaning weight and tropical adaptation in two tropical beef genotypes. Anim. Prod. Sci. 54, 60-73. 